\title{
Medievalista
}

Online

$29 \mid 2021$

Número 29

Representações da ave na Idade Média e suas origens simbólicas

\section{Os cem olhos do pavão}

The hundred eyes of the Peacock: Representations of the bird in the Middle Ages

and its symbolic origins

\section{Marcelo Amato Cardoso}

\section{(2) OpenEdition}

\section{Journals}

\section{Edição electrónica}

URL: https://journals.openedition.org/medievalista/3908

DOI: $10.4000 /$ medievalista.3908

ISSN: 1646-740X

\section{Editora}

Instituto de Estudos Medievais - FCSH-UNL

\section{Edição impressa}

Paginação: 243-275

\section{Refêrencia eletrónica}

Marcelo Amato Cardoso, «Os cem olhos do pavão», Medievalista [Online], 29 | 2021, posto online no dia 01 janeiro 2021, consultado o 11 junho 2021. URL: http://journals.openedition.org/medievalista/3908 ; DOI: https://doi.org/10.4000/medievalista.3908

Este documento foi criado de forma automática no dia 11 junho 2021.

\section{c) (i) (8)}

Mediavalista está licenciado com uma Licença Creative Commons - Atribuição-NãoComercial 4.0 Internacional. 


\section{Representações da ave na Idade Média e suas origens simbólicas Os cem olhos do pavão}

The hundred eyes of the Peacock: Representations of the bird in the Middle Ages and its symbolic origins

\section{Marcelo Amato Cardoso}

\section{NOTA DO EDITOR}

Data recepção do artigo / Received for publication: 28 de Agosto de 2019

Data aceitação do artigo / Accepted in revised form: 5 de Junho de 2020

1 Quando é imaginado o pavão, logo vem à mente o animal de peito azul e cauda multicolorida com formas e padrões que lembram olhos, e cuja exuberância remete à vaidade. A vaidade e o orgulho, prontamente associados ao pavão ${ }^{1}$, embora tenham sido atribuídos à ave desde a Antiguidade, como atesta Esopo ou Cláudio Eliano ${ }^{2}$, parece ser a roupagem simbólica predominante a partir do século XIX, sendo junto com o cravo tema preferido dos artistas Vitorianos e da Art Nouveau, como William Morris (1834-1896), Auguste Delaherche (1857-1940) ou Alfons Mucha (1860-1939).

2 A Antiguidade e a Idade Média não desconsideraram as caracterizações do pavão relacionadas com a vaidade e com o orgulho. Mas os simbolismos da ave nessas épocas parecem ter sido mais ligados a aspectos positivos, desde as divindades e suas virtudes, nos imaginários oriental e greco-romano, até à imortalidade de Cristo e aos pregadores, no ocidente cristão ${ }^{3}$.

\section{Origens simbólicas orientais}

4 Familiar do faisão, o pavão é uma ave originária do Oriente. Embora existam três espécies de pavão, a mais figurada na arte é o Pavão Indiano. Além deste, existem o Pavão Verde, encontrado no sul da China - onde o uso das penas do pavão designava a mais alta categoria dos oficiais da dinastia real de Ming (1368-1644) $)^{4}$ - e em regiões como Tailândia, Birmânia - onde foi eleito emblema de seus monarcas ${ }^{5}$ - e Camboja; e o Pavão do Congo, habitante de florestas tropicais. 
Oriental por natureza, os primeiros registros simbólicos e artísticos do pavão são frutos das criatividades hindu e budista, que fizeram da ave uma acompanhante frequente de suas divindades. Pelo brilho intenso, pelos padrões encontrados nas penas da sua cauda, que lembram estrelas, e pela formação de um círculo quando é aberta em momentos de cortejo, o Hinduísmo fez da ave símbolo do céu, do infinito e de nosso astro central ${ }^{6}$. Isto é, o Sol está sempre em sua forma inteira, brilhando a ponto de ser impossível observá-lo a olho nu, e ainda assim sentir sua influência, tal como os fiéis sentem suas divindades.

6 Para os hindus o pavão é atributo de várias divindades, como a protetora do lar e da agricultura, Lakshmi ${ }^{7}$; Skanda-Karttikeya, o Deus da guerra que monta em Paravani (Fig. 1); a divindade do amor e do desejo Kamadeva ${ }^{8}$, também representada sobre um pavão; a Deusa do conhecimento Sarasvati ${ }^{9}$, e também Krishna - um dos avatares de Vishnu ${ }^{10}$, costumeiramente estampado segurando uma pena de pavão ou acompanhado de $u^{11}$. O destaque do pavão na Índia atravessou milênios, sendo encontrado em relevos do templo budista de Sancha Stupa (séculos I e II a.C.) até que em 1963 foi eleito pássaro nacional.

7 A importância do pavão na Índia foi também prática. A ave, ou partes dela, apresentamse como ingredientes da medicina. O cirurgião Susruta (século VI a.C.) prescreve que o rei deve, diariamente, ter em sua dieta a carne do pavão ${ }^{12}$. E, de acordo com a Charaka Samhita, obra fundamental da medicina tradicional Ayurveda escrita por Charaka (século I? II?), a carne do pavão é benéfica para a visão, audição, inteligência, voz, etc. Apesar de parecer ilógico aos contemporâneos que o fumo das penas de pavão cura picadas de cobra, lembra-se que no período medieval eram usados ingredientes como o chifre do cervo em receitas curativas. O naturalista romano Plínio, o Velho, por exemplo, argumenta que a queima dos chifres do cervo afugenta as cobras e cura epilepsias $^{13}$.

Para os budistas a ave simboliza o conhecimento, mais precisamente os iluminados pela doutrina de Buda (século VI a.C.), chamados bodisatvas, como a Rainha Mahamayuri que, semelhante a Skanda-Karttikeya e Kamadeva, é representada montando num pavão. Isso justifica-se pela habilidade do animal em não se envenenar quando comendo plantas perigosas - conforme contam as histórias orientais -, aproximando-se destes seres iluminados, que conseguem superar pensamentos venenosos a partir da meditação e do autoconhecimento, num processo evolutivo de cinco passos, os quais Choskyi relaciona às cinco penas na cabeça do pavão ${ }^{14}$. 


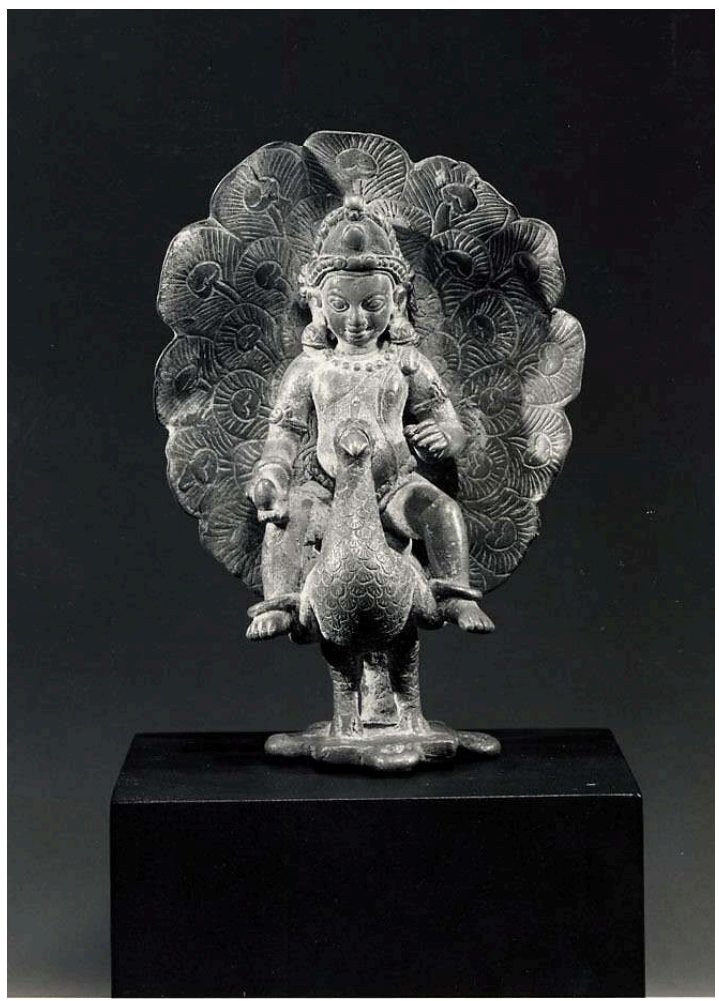

Fig. 1 - Skanda-Karttikeya montado em Paravani, Nepal, séculos XI - XII, liga de cobre, 15 × 10.5 × 64 $\mathrm{cm}$.

(C) Met Museum [Em linha]. (Consultado a 7 julho 2019). Disponível em HTTPS:// WWW.METMUSEUM.ORg/ART/COLLECTION/SEARCH/38333

\section{Do Oriente ao Ocidente}

10 A partir da Índia e de seus comerciantes, o pavão chegou até à região da Pérsia junto ao ouro e às especiarias, e lá adquiriu tamanha dignidade que o trono dos imperadores locais era referido como Trono do Pavão $0^{15}$. Com as conquistas do rei persa Ciro, o Grande (559 a.C.-530 a.C.), o animal, naturalmente sedentário, foi distribuído por todo o império persa Aquemênida, que tinha controle de regiões que iam da Anatólia ao Afeganistão e do Cáucaso à Arábia.

11 Nota-se, porém, que séculos antes disso - se considerados como fontes os textos bíblicos -, o pavão já se encontrava em terras hebraicas, levado pelo rei Salomão (1050 a.C.-931 a.C.) até Jerusalém. As passagens do Livro encontradas em Reis e depois repetidas nas Crônicas, narram a transferência do animal da cidade de Társis até à cidade sagrada dos judeus. De acordo com Jackson, estes são os primeiros relatos da presença do pavão sendo levado em direção ocidental ${ }^{16}$. Os trechos podem, no entanto, conter descrições de relatos esporádicos, como se os animais existissem pontualmente na corte de Salomão e em pequenos números.

12 Lê-se, em Reis:

"Todas as taças que o rei Salomão usava para beber eram de ouro e toda a baixela da Casa da Floresta do Líbano era de ouro puro (...). Com efeito, o rei tinha no mar uma frota de Társis com a frota de Hiram e de três em três anos a frota de Társis voltava carregada de ouro, prata, marfim, macacos e pavões"17.

13 Nair considera que, indubitavelmente, os Fenícios introduziram o pavão na Terra Santa, no Egito e nos reinos da Ásia Menor, uma vez que eram eles quem dominavam o comércio marítimo nas regiões do Golfo Pérsico e Mar Arábico ${ }^{18}$. 
14 Ainda assim, é distante a ideia de que haveria pavões em Jerusalém da mesma forma como haveria, tempos depois, em Roma. Parece que, para o povo do deserto, eles não tinham grande inspiração simbólica nesses primeiros séculos e a presença deles na Terra Santa não representou um fator decisivo para a introdução do animal na Europa, tendo isso mais a ver com as rotas comerciais persas, fenícias e, depois, helênicas.

15 Talvez o pavão tenha sido levado para a Grécia pelos soldados e mercadores das tropas de Alexandre, o Grande (356 a.C.-323 a.C.), que encontraram no animal um objeto valioso. $O$ imperador helenístico, conta-se, levou duzentos pavões para a Macedônia ${ }^{19}$. Porém, argumenta-se que o pavão já era conhecido na Grécia antes do tempo de Alexandre ${ }^{20}$. Teria havido uma diáspora de descendentes dos pavões de Salomão? Um produto disseminado pelos fenícios? Ou pelas rotas Aquemênidas? Não existe convergência sobre a origem dos pavões na Grécia, mas é verdade que autores antes do período de Alexandre já conheciam a ave.

Uma possível rota até chegar no continente foi a partir da conquista pelos atenienses da ilha de Samos, que havia recebido o pavão de comerciantes do Oriente Médio e eleito o animal como símbolo da divindade nascida na ilha, Hera, a protetora dos lares, do casamento e do parto ${ }^{21}$. Depois da morte do tirano Polycrates (?-522 a.C.), a ilha de Pitágoras (570-490 a.C.) e de Epicuro (341-270 a.C.) foi dominada pelos persas e no século V juntou-se à Liga de Delos sob domínio de Atenas. Foi durante esses dois marcos que o pavão provavelmente chegou à Samos. O poeta cômico grego Antífanes (408 a.C.-334 a.C.) confirma a relação entre a ilha de Samos, a deusa Hera e o pavão:

"Hera, eu ouvi

Em Samos mantém esse tipo de pássaro dourado

O admirável e adorável pavão". ${ }^{22}$

17 Assim que o animal chegou ao território grego e à península itálica, foi representado puxando a carruagem de Hera, a partir da tradição de Samos; e associado a Juno, a rainha dos céus, esposa do Zeus, Deus celeste e protetor dos romanos Júpiter ${ }^{23}$, cujas sacerdotisas carregavam leques cerimoniais feitos com penas de pavão, chamados flabelli ${ }^{24}$.

18 Lembrando o céu estrelado, a plumagem do pavão representou Hera, filha de Kronos e Rheae esposa/irmã do pai do panteão grego, Zeus ${ }^{25}$. A mitologia apresenta que a divindade de Samos quase surpreendeu a traição de Zeus com Io, transformada pelo poderoso em uma bezerra, que Hera exigiu como presente. A fim de afastar Io de seu marido/irmão, a deusa colocou o titã gigante de cem olhos Argos Panoptes vigiando o animal. Zeus, em sequência, deu ordem a Hermes para assassinar o titã e libertar a amante em forma de bezerra. Como tributo e agradecimento pelo serviço prestado, Hera colocou os olhos do titã em um pavão, que então ganhou os cem olhos em sua cauda ${ }^{26}$.

Como comparação, a tribo indiana de Gadaba, de Ghallanguda, no distrito de Koraput, tem uma versão diferente sobre a origem da cauda do pavão. Conta-se que um xamã sacrificou uma vaca para Jaker Deota, e colocou uma tira de carne no telhado de sua casa para secar. Na manhã seguinte, sua esposa, enquanto varria a varanda da casa, assistiu a um papagaio tentando arrancar um pedaço da carne. A mulher, então, jogou sua vassoura no papagaio e o acertou. Foi quando a vassoura se transformou no pavão, mantendo o colorido do pássaro e as cerdas da vassoura ${ }^{27}$. 
20 Fora do contexto mitológico, são vários os autores clássicos que escreveram sobre o pavão e, nesse caso, já fazendo associações entre o animal e o orgulho ou vaidade. Lê-se na fábula do grego Esopo (620 a.C.-564 a.C.), o Pavão e a Grua:

"O pavão zombava da grua por causa da cor de sua plumagem:

Minha roupa é de ouro e púrpura, já a tua plumagem não tem nenhuma beleza.

Só eu - respondeu a grua -, canto entre as estrelas, e meu voo me leva às alturas; tu, igual a um galo, caminhas pela terra como a galinhada.

Melhor a glória em andrajos que a desonra no fausto" 28

O grego Aristóteles (384 a.C.-322 a.C.) em sua História dos Animais mantém ao pavão uma caracterização mais negativa que positiva. Em relação ao temperamento dos animais, considera o pavão um animal invejoso e orgulhoso de seus próprios ornamentos ${ }^{29}$.

Da Grécia a ave foi levada a Roma e espalhada pelo continente, chegando até a Inglaterra, como comprovam os mosaicos das vilas Keynsham e Woodchester (séculos II e IV $)^{30}$. E, no segundo século havia tantos pavões que garantiam a todos os nobres romanos a aquisição de $u^{31}$, sendo portanto natural que autores romanos também tenham escrito sobre o animal, e que os artistas tenham garantido ao pavão representações em mosaicos e pinturas murais, em especial na arte funerária, que influenciou a arte dos primeiros cristãos.

Plínio, o Velho (23-79), apresenta uma narrativa mostrando elementos como o orgulho do animal, o brilho e colorido de suas penas e a sua presença na culinária:

"Vamos agora falar da segunda classe de pássaros, que é dividida em dois tipos; aqueles que dão presságios pelos seus tons, e aqueles que proporcionam presságios pelo seu vôo. (...) Estes últimos, portanto, serão tratados por primeiro, e o pavão deverá preceder ao resto, tanto pela sua beleza singular quanto pelo seu instinto superior, e pela vaidade que exibe. Quando ouve ser elogiado, este pássaro espalha suas cores esplêndidas, e especialmente caso o sol estiver brilhando no momento, porque assim elas são vistas em todo esplendor, e com melhor superioridade" 32

O autor e professor de retórica romano Cláudio Eliano (175-235) mais uma vez associa o pavão com o orgulho e beleza. Estes, então, mostram-se como os dois atributos mais recorrentes nas narrativas greco-romanas:

“O pavão sabe que é o mais belo dos pássaros; sabe também onde reside sua beleza; orgulha-se disso e é arrogante, e ganha confiança pelas plumas que são seus ornamentos e que inspiram o terror aos estranhos" ${ }^{33}$. Persa e espalhando-se pelo império Helenístico e depois pelo restante da Europa, o pavão chegou à Idade Média com simbolismos ambíguos, assim como grande parte dos animais descritos nos bestiários, manuscritos monásticos que apresentam-se aqui como importante repertório alegórico da natureza. Chegou como um animal de imensa beleza, relacionado ao orgulho e a vaidade desde a Antiguidade. E por sua beleza, especialmente, o pavão é encontrado em dezenas de iluminuras e marginálias de manuscritos medievais.

Nas iluminuras do pavão encontradas nos bestiários, a cauda do animal, e principalmente seus ocelos, são os aspectos mais evidenciados pelos artistas, como no Bestiário de Ashmole (século XIII, Fig. 2). 


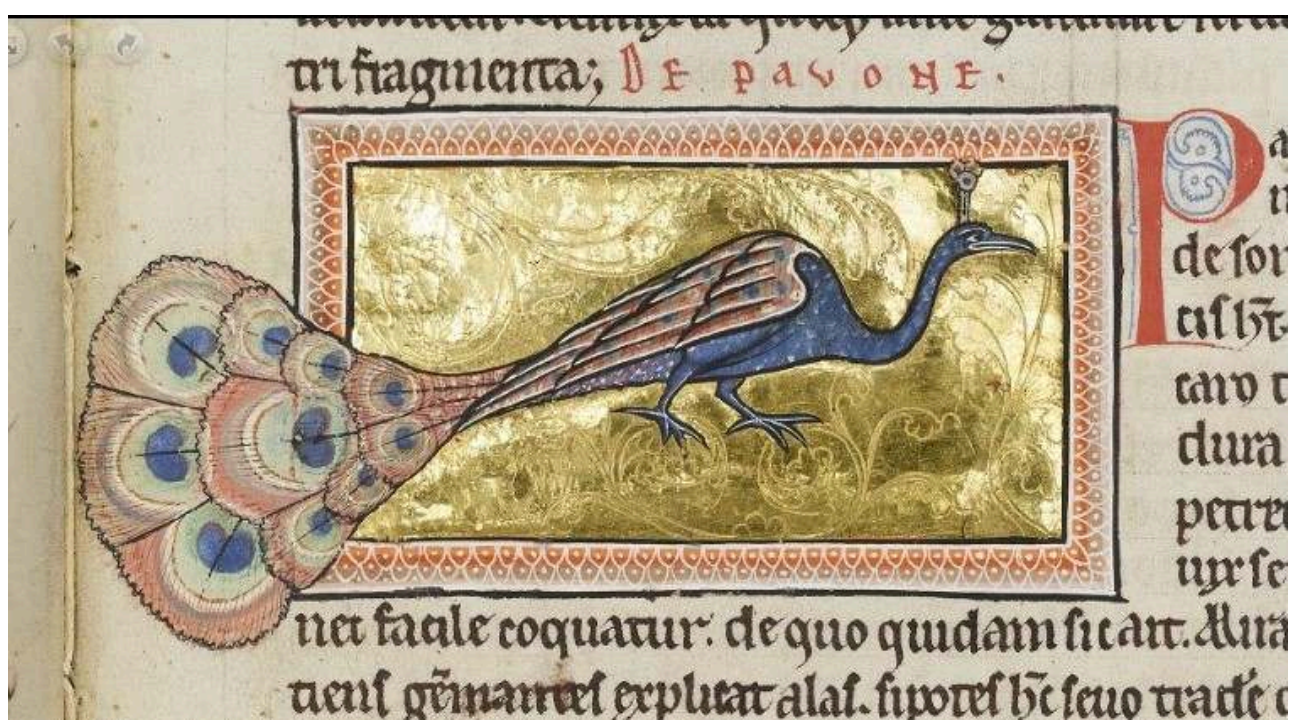

Fig. 2 - Bestiário Ms. Ashmole 1511, f. 72r, Peterborough ou Lincoln, século XIII.

(c) Bodleian Library, University of Oxford [Em linha]. (Consultado a 7 julho 2019). Disponível em

HTTPS://DIgITAL.BODLEIAN.OX.AC.UK/INQUIRE/P/1F239D71-6019-406A-8310-DF5538AEB2C9

As marginálias podem estar habitadas por pavões que bastante lembram o animal como ele é na natureza, mas também de forma fantástica, como o pavão-leão do manuscrito turco Maravilhas da Criação (século XIII), composto por Zakariya' al-Qazwini (Fig. 3).

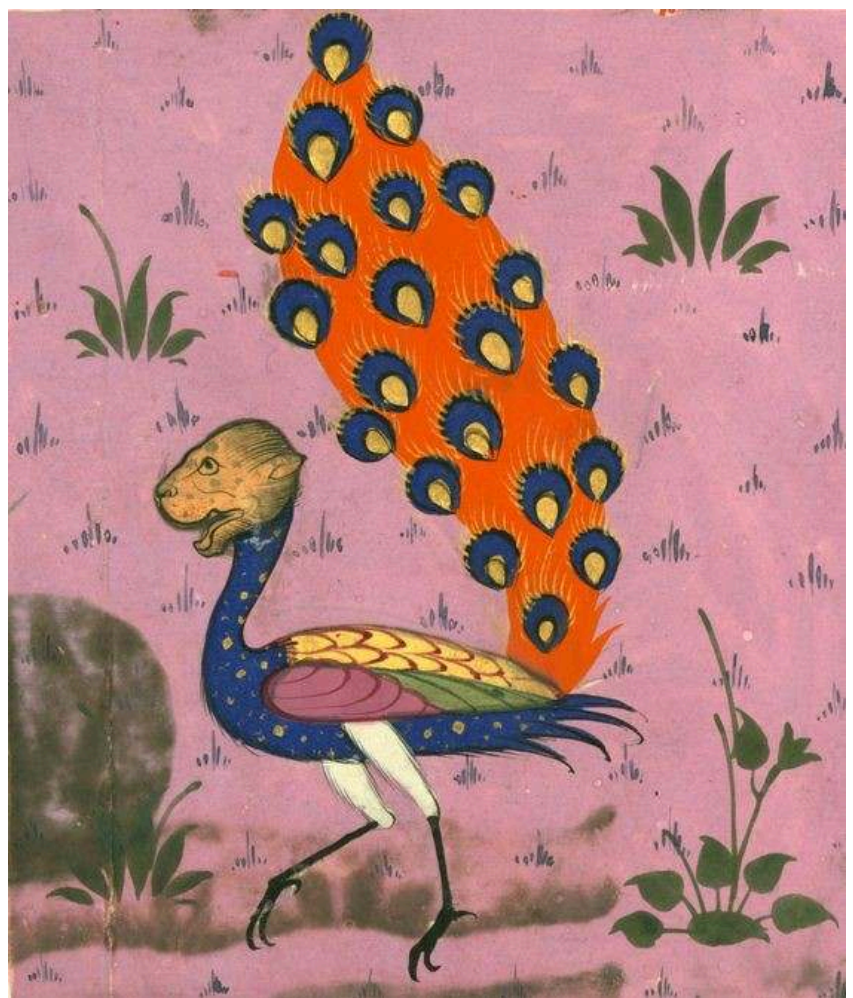

Fig. 3 - Zakariyā' al-Qazwīnī, Maravilhas da Criação. Baltimore, Walters, Ms. W.593, fol. 178a. Turquia, século XIII.

(C) The Digital Walters [Em linha]. (Consultado a 7 julho 2019). Disponível em HTTP:// WWW.THEDIgITALWALTERS.ORg/DATA/WALTERSMANUSCRIPTS/HTML/W593/DESCRIPTION.HTML

Ainda que inúmeros manuscritos chamem atenção para a beleza do pavão, na época a ave ganhou contornos místicos mais positivos em relação aos períodos predecessores (e 
posteriores), e as produções culturais da era focaram-se especialmente na relação entre o pavão e o Cristo imortal.

A imortalidade sendo simbolismo do pavão durante a Idade Média pode ser explicada a partir de três principais origens. A primeira é da crença de que a carne do pavão não se decompõe. A segunda é a partir da tradição oriental de Skanda-Karttikeya. E a terceira a partir da herança artística da Antiguidade, quando o animal era ilustrado em espaços funerários pagãos e cristãos.

31 Não é possível determinar como chegou aos europeus a ideia de que a carne do pavão não se decompõe e nem apodrece. Jackson dá uma possível explicação, argumentando que a carne do pavão quando seca ao sol (prática encontrada na história da tribo indiana de Gadaba), depois de temperada com especiarias, torna-se rija e, por esta razão, decompõe-se mais lentamente que outras carnes ${ }^{34}$.

Foi essa característica que tornou possível a associação do pavão com Cristo e Sua imortalidade. Santo Agostinho (354-430) escreveu sobre as duas habilidades da ave que a associaram à imortalidade: a sobrevivência do corpo do pavão e a troca de suas penas todos os anos. $\mathrm{Na}$ obra Cidade de Deus, exemplificando animais que tem seus corpos preservados após a morte, o doutor da Igreja explica:

"Quem senão Deus, criador de todos os seres, deu à carne do pavão real não corromper-se depois da morte? Isso, à primeira vista, parece incrível. Mas um dia, em Cartago, serviram-nos um prato dessa ave. Tomei um pouco do peito, carne magra, e mandei guardá-lo. Ao cabo de tempo suficiente para se corromper qualquer outra carne cozida me apresentaram aquele pedaço e ainda não ofendia o olfato. Vi-o, mais de um mês depois, no mesmo estado. E, depois de um ano, apenas estava um pouco mais seco e mais encolhido" ${ }^{35}$.

O franciscano Marcus de Orvieto (século XIII) compara a carne íntegra da ave com aqueles enraizados nas virtudes evangélicas e com o cheiro da boa reputação ${ }^{36}$. A segunda Carta aos Coríntios, mencionada na obra do seguidor de São Francisco (1182-1226), Liber de Moralitatibus, aponta: "Graças sejam dadas a Deus, que por Cristo nos carrega sempre em seu triunfo, expande em toda parte o perfume de seu conhecimento. Em verdade, somos para Deus o bom odor de Cristo" ${ }^{37}$.

Abre-se um parêntesis para notar que tanto em Santo Agostinho como em Plínio, encontramos a apropriação do pavão pela culinária. O costume é ainda mais antigo, já que imperador indiano Asoka (século III a.C.), antes de convertido ao budismo, tinha o pavão em seu cardápio ${ }^{38}$. Lê-se no De Re Coquinaria, do gastrônomo romano Apicius (25 a.C.-37 d.C.): "As almôndegas de pavão ficam em primeiro lugar se forem fritas até que amoleçam a pele" 39 . Nos banquetes medievais esta ave também era servida, com as penas reatadas ao seu corpo. Embora não tão popular, a receita aparece no livro culinário Le Viandier (c. 1300), por muito tempo atribuído a Guillaume Tirel $(1310-1395)^{40}$. A prática de vestir com suas penas o pavão depois de assado aparece na tradição cavaleiresca dos "votos do pavão", quando o cavaleiro impõe sua mão sobre o animal e jura servir bem o reino e ter ações heróicas ${ }^{41}$ (Fig. 4). Será que para os medievais aquilo que era considerado bonito deveria ter um bom gosto? 


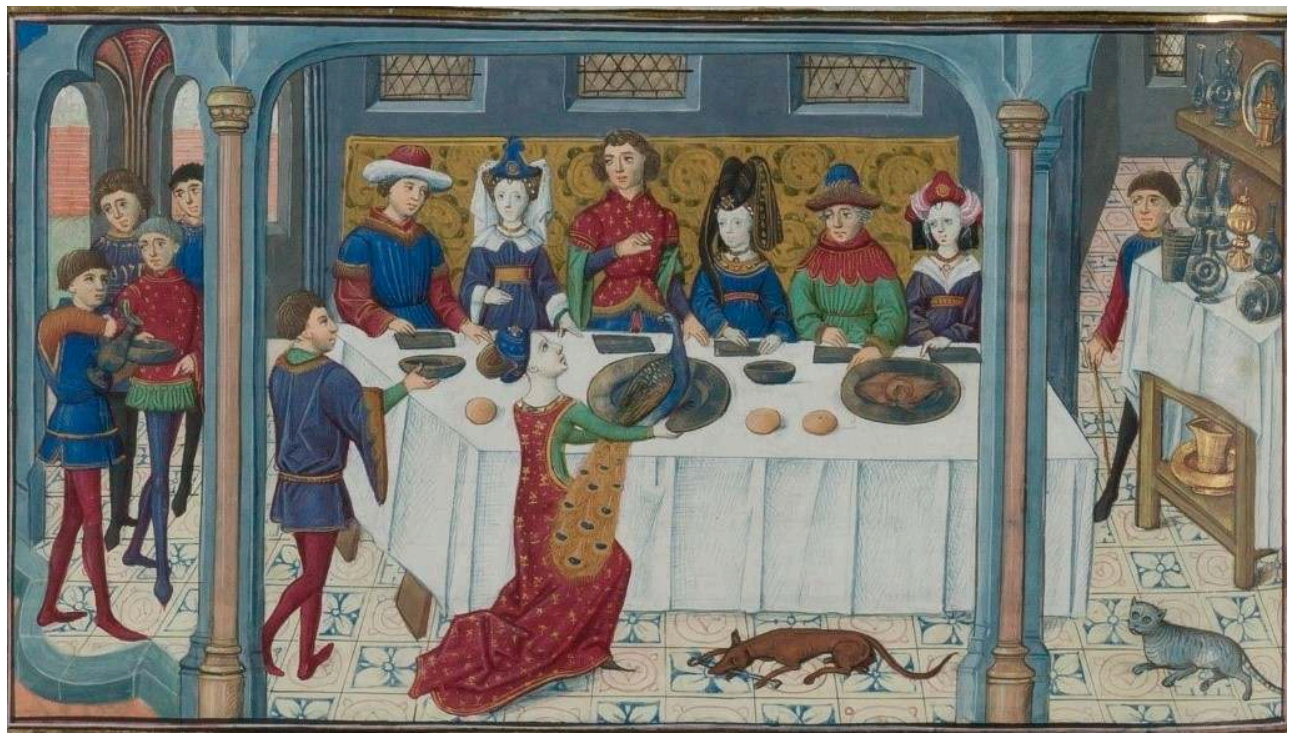

Fig. 4 - Os votos do pavão, Le Livre des conquestes et faits d'Alexandre, f. 86r, Paris, século XV. Museu do Petit-Palais.

(C) IRHT-CNRS / Petit Palais [Em linha]] (Consultado a 7 julho 2019). Disponível em HTTP:// WWW.PETITPALAIS.PARIS.FR/OEUVRE/LIVRE-DES-CONQUESTES-ET-FAITS-D-ALEXANDRE\#.

Fecha-se o parêntesis a respeito da ave na culinária e volta-se a descrever as tradições que levaram os medievais a atribuir ao pavão o símbolo da imortalidade. A segunda fonte de inspiração vem do Oriente. A tradição conta que Skanda-Karttikeya, o deusguerreiro que monta no pavão Paravani, transforma o veneno das cobras em poções da imortalidade. 0 próprio Paravani tem sua beleza derivada da prática de matar as cobras: "Acredita-se que a beleza da sua plumagem deriva da transmutação natural dos venenos que engole quando destrói serpentes" ${ }^{42}$.

Em terceiro lugar, e talvez mais significativa, a ideia do pavão como signo do imortal aparece na arte funerária. Nela, a ave aparece em composições murais junto a outros símbolos da imortalidade, também relacionados ao paraíso, como o pombo, as vinhas, os cântaros e ânforas, as guirlandas, entre outros. No complexo arqueológico romano de Viminacium, na atual Sérvia, encontram-se dois pavões junto a uma ânfora, interpretado como símbolo da imortalidade ${ }^{43}$ (Fig. 5). 


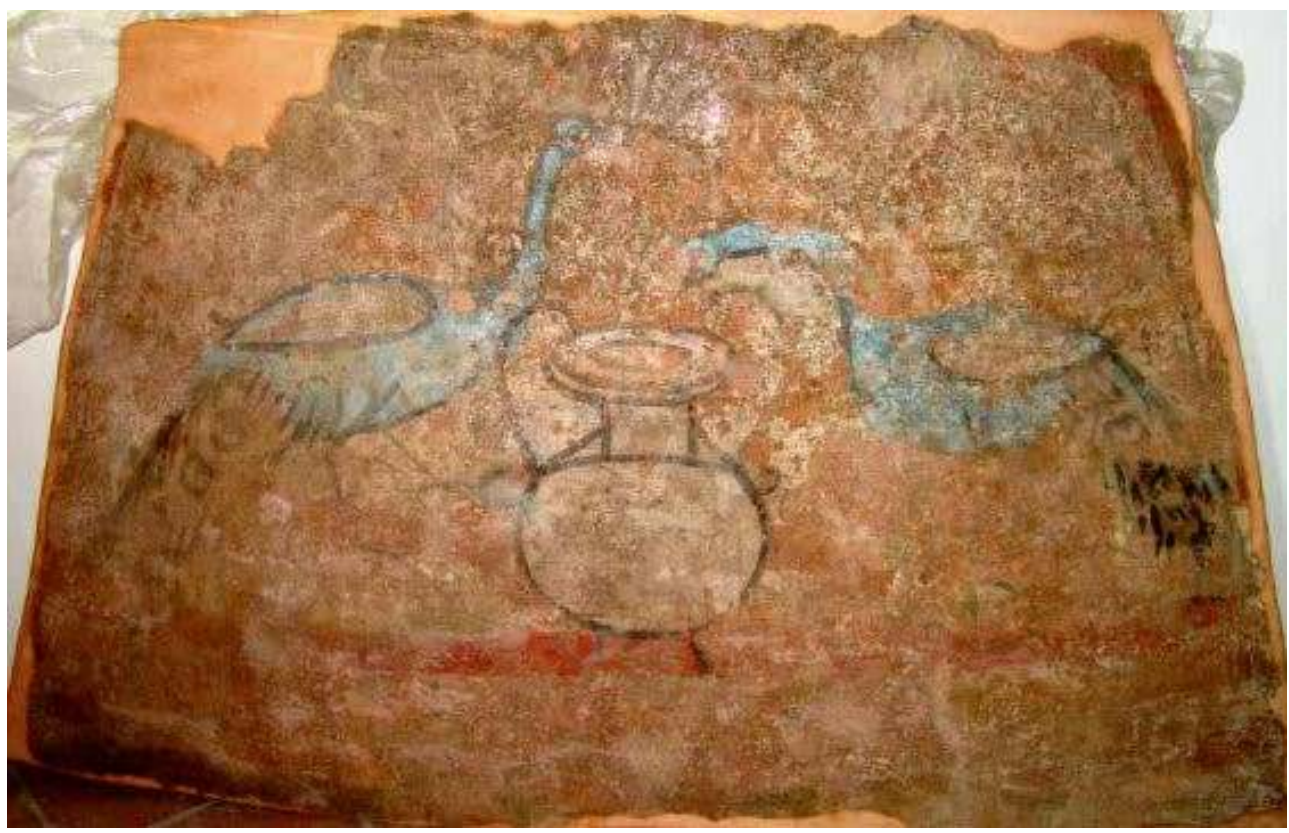

Fig. 5 - Pavões e ânfora na tumba G-5464, Viminacium, século I.

(c) ANDELKOVIC, Jelena; ROGIC, Dragana; NIKOLIC, Emilija. "Peacock as a sign in the late antique and early christian art". Archeology and Science 6 (2010), pp. 231-248, 234.

Pela permanente meditação sobre o ciclo da vida, o imaginário do pavão como símbolo da imortalidade passou da arte pagã à cristã com naturalidade. 0 animal figurou na arte dos seguidores de Cristo nas catacumbas, junto às vinhas, aos pombos, ao monograma de Cristo - XP -, e da Árvore da Vida encontrada no centro do Jardim Celestial, como escrito no texto bíblico: "Quem tem ouvidos, ouça o que o Espírito diz às Igrejas: ao vencedor, conceder-lhe-ei comer da árvore da vida que está no paraíso de Deus” ${ }^{44}$.

A composição do pavão duplicado bebendo de um cálice ou cântaro, tal como encontrado em Viminacium, é a mais usada na arte medieval. Ela pode ser encontrada em imagens na Basílica de Santa Maria Donato, em Murano (século XII, Fig. 6), na Basílica de Santa Maria Assunta, em Torcello (fundada em 639), na ábside da Basílica de São Clemente, na capital italiana (século XII), no Palácio Jaisalmer no Rajastão (século XII), entre outros. Não se restringindo às artes monumentais, há composições dessa natureza também em manuscritos, como na Bíblia Sancti Martialis Lemovicensis (século XI, Fig. 7) ou no Evangelho de T'Oros Roslin (1262).

Em contextos funerários, encontram-se pavões, por vezes também duplicados, em frescos da Necrópole Vaticana (século I), da Catacumba de Priscilla (século III), do Hipogeu da Via Dino Compagni (século IV), os três em Roma, e da Catacumba São Genário (século VI), em Nápoles. Também são encontradas as aves nos sarcófagos de pórfiro de Constantina (século IV), destinado à filha de Constantino (272-337), e em outro reaproveitado pelo Bispo Teodoro, na Basílica São Apolinário in Classe, em Ravena (século V, Fig. 8). 


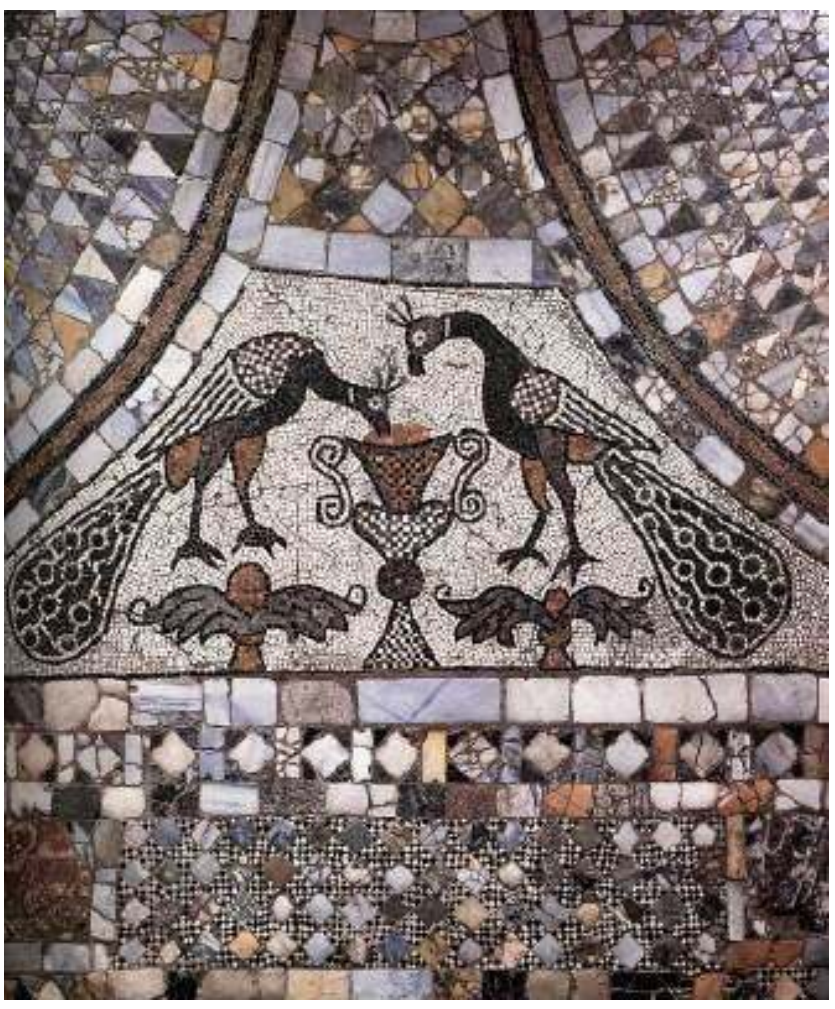

Fig. 6 - Mosaico no pavimento da Basílica de Santa Maria Donato, Murano, século XII. (c) Commons Wikimedia [Em linha]. (Consultado a 7 julho 2019). Disponível em HTTPs:// COMMONS.WIKIMEDIA.ORg/WIKI/ CATEgORY:PAVEMENT_OF_SANTA_MARIA_AND_SAN_DONATO_(MURANO)

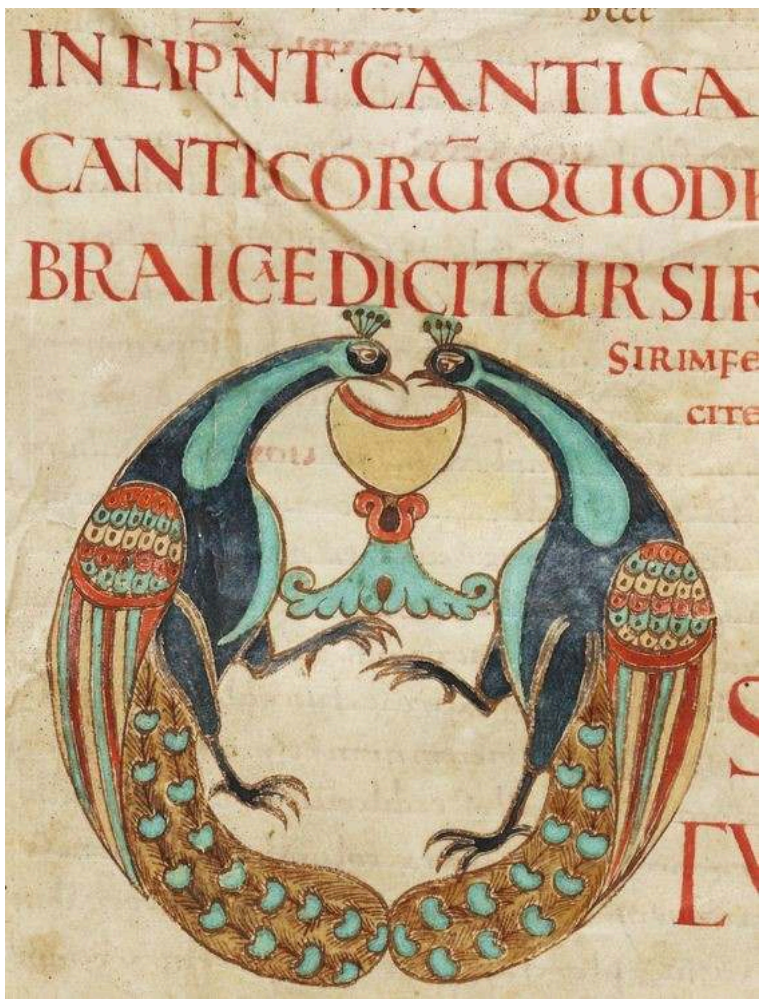

Fig. 7 - Bíblia Sancti Martialis Lemovicensis, pars. II, Latin 5(2), f. 51r, S. Martial de Limoges, século IX. (c) BnF - Bibliothèque nationale de France [Em linha]. [Consultado a 7 julho 2019]. Disponível em HTTPS://gALLICA.BNF.FR/ARK:/12148/BTV1B8530347K/F109.IMAgE. 


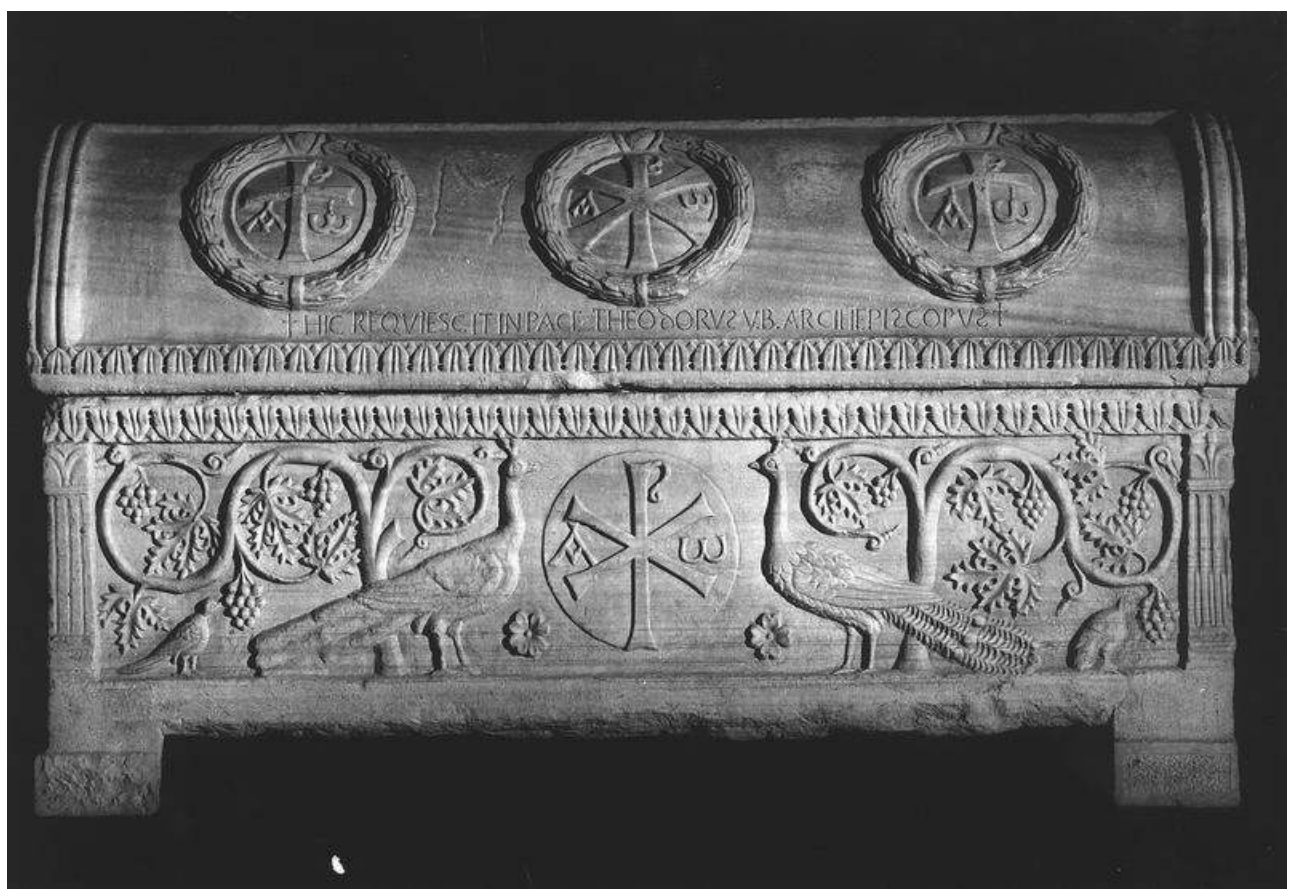

Fig. 8 - Sarcófago de Teodoro, na Basílica São Apolinário in Classe, mármore, Ravenna, século V. (C) Byzart.eu - Byzantine Arte and Archeology on Europeana [Em linha]. (Consultado a 7 julho 2020). Disponível em HTTPS://CMC.BYZART.EU/ITEMS/SHOW/12384)

Apesar da escassez de fontes escritas até à Alta Idade Média, o pavão figurou em diversos espaços religosos com a temática da dupla de pássaros cercando um cálice, comumente junto às vinhas, aos acantos e à Árvore da Vida. A arte, portanto, confirma a relação entre o pavão e a imortalidade.

41 Como consequência, então, o pavão tornou-se símbolo daquele que venceu a morte, Cristo. Era comum na Idade Média associar o Salvador aos mais diferentes animais, em especial aqueles mais ligados aos poderes natural e espiritual, como o unicórnio, o cervo, o leão ou a pantera. Assim, pode-se interpretar a figura do pavão nas artes medievais como um emblema de Cristo.

Outra demonstração que pode ser feita da aproximação de Cristo com o pavão é a inimizade deste com as cobras. Lembre-se o pavão de Skanda, Paravani, o matador de cobras, e da prática de queimar as penas da ave para afugentar as rastejantes. Recordese também que, mesmo com uma dieta baseada em grãos, pequenas plantas e arbustos e insetos, o pavão também se alimenta de cobras. A divindade hindu Garuda é ilustrada matando uma serpente ${ }^{45}$. E mesmo que Garuda seja considerado um homem-águia, foi das suas penas que foi criado Mayura, este por sua vez em formato de pavão. A palavra mayura, no sânscrito, significa pavão $0^{46}$. Na Idade Média, as cobras são mesmo signos do diabo, "o grande Dragão, a antiga serpente, o chamado Diabo ou Satanás, sedutor de toda a terra habitada" ${ }^{47}$. Portanto, afastar o pavão da serpente representa, simbolicamente, o combate entre o bem e o mal, entre Cristo e o diabo.

\section{Os simbolismos do pavão no Islão}

44 A relação do pavão com a cobra aparece também na tradição islâmica. Para os seguidores de Maomé (570-632), o pavão tem também simbolismos ambíguos.

45 Na literatura, o pavão é encarado como um dos mais bonitos animais criados por Allah. $\mathrm{E}$, ao mesmo tempo, é relacionado com a serpente que leva o fruto proibido à Eva e ao 
anjo caído $\mathrm{Iblis}^{48}$, nominado Shaitan no Corão. No que diz respeito aos primeiros simbolismos, cita-se o Nahjul al-Balaghah, um compêndio de textos teológicos escrito pelo poeta xiita Sharif Razi (século X), contendo mais de duzentos sermões supostamente feitos pelo quarto califa e último profeta do Islã, Ali ibn Abi Talib (601-661), primo e genro de Maomé. No Sermão 164, lê-se sobre a criação do pavão:

"Você iria imaginar que suas plumagens são varas de prata e que os maravilhosos círculos e penas em formato de sol crescendo sobre o mais puro ouro e peças de verde esmeralda. Se você comparasse a qualquer coisa crescida na terra, diria que é um buquê de flores coletadas durante toda a primavera. Se você os comparasse a panos, eles seriam estampados e surpreendentes panos variegados do Iêmen. Se os comparasse a ornamentos, eles seriam como pedras preciosas de cores diferentes com prata cravejada (...)" ${ }^{49}$.

Diferente da tradição cristã, onde o pavão e a serpente tornam-se animais antônimos, na islâmica, os dois são em alguns casos tidos como parceiros e, por vezes, confundemse. Autores islâmicos compilaram as histórias dos profetas na obra Qisas al-Anbiya. Nessa obra existe a associação do pavão, da serpente e do anjo caído, Iblis. Conta-se que o anjo se recusou a prostrar-se diante de Adão e, por consequência, foi expulso do paraíso uma atitude igualmente ambígua, já que a recusa de Iblis pode ser encarada como uma demonstração de seu monoteísmo. Tentando voltar ao Paraíso, o anjo caído usa o pavão em sua estratégia, ameaçando a ave de extirpar sua beleza caso ela não consiga roubar o fruto da Árvore da Vida. A serpente, nova personagem introduzida na história, reúnese ao pavão e ao Iblis e consegue o fruto. o pavão, depois, carrega o anjo caído em sua boca e o leva até o Paraíso. Na tradição muçulmana, aliás, é partir da corrupção do pavão que as presas da serpente tornaram-se venenosas ${ }^{50}$.

de Jacques Derrida (1930-2004), Syme argumenta que a fé está relacionada com a cegueira e, portanto, a interrupção da visão é uma forma de castração ou submissão à vontade de Deus. É a cegueira física que possibilita o despertar da verdadeira visãa ${ }^{53}$. Nas palavras de Jesus, "Para um discernimento é que vim a este mundo: para que os que não veem, vejam, e os que veem, tornem-se cegos. (...) Se fôsseis cegos, não teríeis pecado; mas dizeis: 'Nós vemos!'. Vosso pecado permanece" ${ }^{54}$. Torna-se difícil definir os cem olhos do pavão como símbolos da visão verdadeira ou como símbolos do próprio pecado. Mas, parece verdadeiro que podem ser interpretados como figuras alegóricas que mostram a necessidade da castração ou da cegueira do fiel a fim de aproximá-lo da Igreja.

50 Também relacionando o pavão e a Igreja, os bestiários apresentam a ave como símbolo dos membros dela: os doutrinadores, os pregadores e os santos.

51 A narrativa se inicia com a explicação do nome do pavão: "O pavão recebe seu nome, pavo, pelo som de seu choro" ${ }^{55}$. Em seguida, o documento comenta sobre a dureza da carne no animal e a dificuldade em ser cozida, e, citando um trecho de Epigrama, do 
poeta hispânico Marcus Valerius Martialis (38? 41?-102? 104?), nota a semelhança das asas do pavão com jóias: "Você está perdido na admiração, sempre que ele abre suas asas cheias de jóias; você consegue entregá-lo, mulher do coração endurecido, ao cozinheiro insensível?" ${ }^{56}$.

Depois, apresenta as já citadas passagens bíblicas que descrevem a transferência dos pavões, de Társis para Jerusalém pela frota de Salomão. O clérigo francês Hugo de Foilloy (1096? 1111?-1172), em seu Aviarium, interpretou tais passagens da seguinte forma: em primeiro lugar, Salomão retirava de Társis os animais que simbolizam a zombaria e a sensualidade, respectivamente o macaco e o pavão. Assim, o povo de Társis poderia viver humildemente com a recente conversão. Então, os três anos que levavam até frota de Salomão chegar ao destino, seriam alegoricamente, a meditação, a declaração e a ação. Portanto, a retirada do pavão da condição de sensualista é realizada a partir da sua transferência para Jerusalém, tornando-se símbolo então ligado aos sermãos e aos fiéis ${ }^{57}$.

53 É esta também a interpretação dada pelo Bestiário de Aberdeen. Depois de explicar mais uma vez a etimologia do nome do animal, o Bestiário de Aberdeen cita a característica de que a carne do pavão não se deteriora. E discute-se, também, a relação simbólica da carne do pavão e dos pregadores cristãos:

"O pavão tem carne dura, resistente à decomposição, que só pode ser cozida com dificuldade, e com esforço pode ser digerida no estômago, devido ao calor de seu vivente. Tais são as mentes dos professores; eles também não queimam com a chama do desejo, nem são incendiados pelo calor da luxúria (...). O pavão tem uma voz temerosa, assim como um pregador quando ameaça os pecadores com o inextinguível fogo de Geena. Ele caminha sem se afetar, no sentido de que o pregador não ultrapassa os limites da humildade em seu comportamento. (...) 0 pavão tem cabeça de serpente, enquanto a mente do pregador é mantida sobre sábia discrição. Mas, a cor safira de seu peito significa que o pregador anseia mentalmente pelo paraíso. A cor vermelha nas penas do pavão significa seu amor pela contemplação"s8.

Vê-se, portanto, que tão incorruptível quanto a carne do pavão é a mente dos pregadores cristãos. Tão temerosa quanto a voz da ave é a palavra de tais pregadores em direção aos pecadores, ação comparada ao fogo de Geena, que é descrito na Bíblia como destinado aos ímpios: "Caso o teu olho direito te leve a pecar, arranca-o e lança-o para longe de ti, pois é preferido que se perca um dos teus membros do que todo o teu corpo seja lançado na geena" ${ }^{59}$.

É interessante notar a solução dos redatores para não ser inteiramente atribuído ao pavão o simbolismo herdado da Antiguidade, como de um animal orgulhoso e vaidoso, e sim usar dessas noções para inspirar o leitor a buscar a humildade.

Encontra-se que o pavão pode sim erguer sua cauda exuberante mas, em contrapartida, deixa sua parte traseira exposta, tal como um pregador é ridicularizado quando se torna orgulhoso: "Mas quando o pavão levanta sua cauda, expõe seu traseiro, da mesma forma que tudo o que é elogiado na conduta de um professor, é ridicularizado quando ele sucumbe ao orgulho. $O$ pavão, portanto, deve manter seu rabo abaixado, assim como aquilo que um professor faz, deve ser feito com humildade" ${ }^{60}$.

O franciscano António de Lisboa (1195-1231) em um de seus Sermões Dominicais apresenta ideia semelhante. Comparando-o ao avestruz, o santo da capital portuguesa anota sobre o pavão que: “(...) ao ser louvado pelas crianças mostra o esplendor das suas 
penas, e quando faz rodar a cauda descobre torpemente os traseiros. Assim o hipócrita, ao louvar-se, mostra as penas da santidade que julga ter e faz a roda da sua vida" ${ }^{61}$.

É também a partir da beleza do pavão e o risco que o animal corre em sucumbir à vaidade, que o Physiologus, obra compilada possivelmente em Alexandria entre os séculos III e IV, busca uma alegoria para a aspiração cristã da humildade e da caridade. Aqui, não é a exposição da parte traseira a contrapartida simbólica do pavão demonstrar sua vaidade e orgulho, e sim a tristeza do animal em olhar seus próprios pés, tão feios se comparados à sua cauda:

"Pavão é muito bonito, anda com grande beleza (...). E quando ele vê seu pé, ele chama tristemente e diz: Oh! Senhor, por que você não cria meu pé como meu corpo! Então, você também, homem, cuide de todas as maravilhas de Deus lhe deu. (...) Você está olhando ao ouro e prata em você, e não se lembra dos pobres. Pegue muitos dos dons de Deus e os entreguem à pobreza para transformar sua alma em vida eterna. Se você se machuca, pede ao médico pela cura. Cure suas feridas mentais, porque o remédio para alma é a Igreja e a caridade" 62 .

Além da relação com os membros do clero e com o Filho de Deus, existem exemplos iconográficos que situam o pavão junto a diferentes santos e cenas bíblicas. Mesmo que possam ser associadas as penas às auréolas dos santos, cada um deles relaciona-se à ave por determinadas razões, diferentes e únicas entre eles. Existem alguns exemplos interessantes na arte medieval onde o pavão, ou sua pena, é incorporado ao tema dos santos e às temáticas bíblicas.

61 No bizantino Evangelho de Rabbula (século VI) encontra-se a dupla de pavões em pelo menos duas cenas, acompanhando o altar da Virgem e também junto aos santos Eusébio de Cesareia (265-339), bispo e historiador da Igreja, e o filósofo Amônio de Alexandria (século III). E esse mesmo arranjo aparece junto a São Pedro (século I), numa placa bizantina de prata (século VI) que mostra o apóstolo carregando a chave dos céus.

O Livro de Kells, ou Evangeliário de São Columba (c. 800), produzido por monges irlandeses, apresenta o pavão em várias situações, sendo duas delas mais significativas. A primeira mostra a dupla das aves na parte superior do fólio, e, em seu centro a imagem de Cristo. A segunda mostra a ave em meio ao trecho da passagem de João "Quia descendi de caelo" ("Pois desci do céu") ${ }^{63}$. As duas referências tornam-se importantes para comprovar a figuração da ave como elemento (Figs. 9 e 10) ${ }^{64}$.

Medievalista, 29 | 2021 


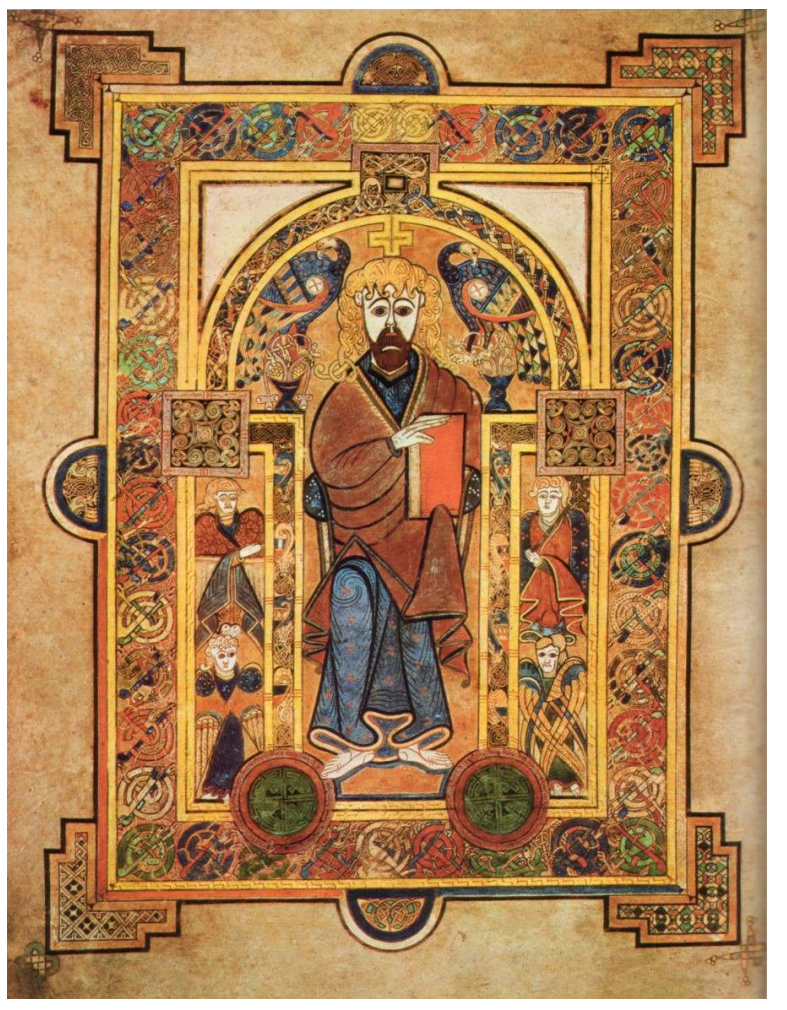

[uoodaconihi p
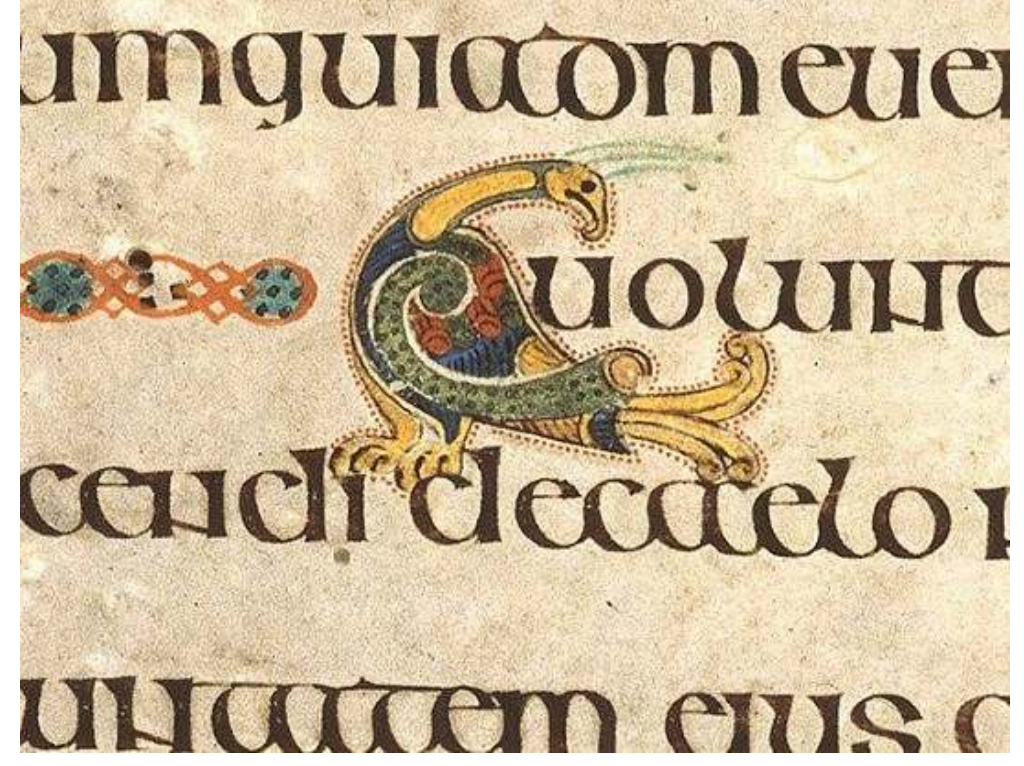

Fig. 9 e 10 - Detalhes do Livro de Kells. MS A. I. (58), f. 32v e f. 309r, Northumbria, c. 800.

(c) Trinity College, Dublin, Irlanda [Em linha]. Consultado a 7 julho 2020). Disponível em HTTPS://

WWW.THEgUARDIAN.COM/BOOKS/gALLERY/2012/DEC/14/BOOK-KELLS-PICTURES.

O Apocalipse de Paris (século XV) ${ }^{65}$ exibe a cena do Cristo entronado ao centro de sua amêndoa mística, junto com figuras angelicais ajudando São João subir aos céus. Dentre as figuras angelicais, a central apresenta asas com penas de pavão. Acompanham Cristo 
os quatro evangelistas, Mateus, Marcos, Lucas e João rodeando o Senhor em sua mandorla. Os quatro evangelistas, em outro documento, a Bíblia de Nicolaus de Lira (c. 1402), aparecem também com penas de pavão nas asas e em seus formatos animais Tetramorfos: Homem-anjo, Leão, Boi e Águia (Fig. 11).

Nota-se a imagem do anjo com asas de pavão é bastante misteriosa, já que lembra o anjo caído Íblis da tradição islâmica. Estes anjos com asas feitas de penas evocam também a imagem do Pavão Angelical, personagem encontrado na tradição dos Yazidis comunidade étnico-religiosa curda -, que o chamam de Malik Taus, a manifestação de sua divindade mais importante ${ }^{66}$. Ainda que tanto os Yezidis quanto os medievais tenham em seu imaginário a figura de um anjo com asas de pavão, não há, ainda, como defender uma possível influência ou conexão entre os dois.

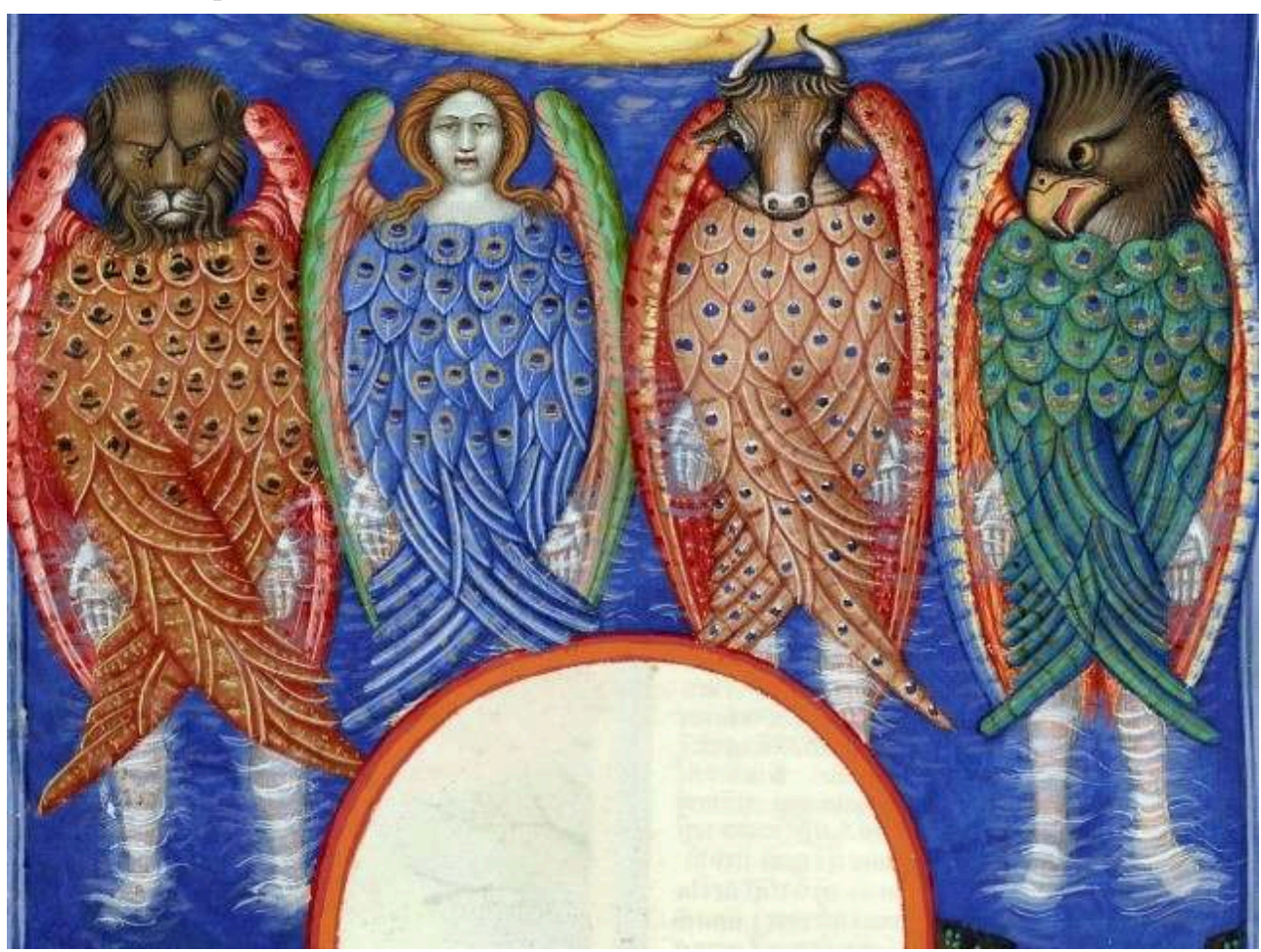

Fig. 11 - Bíblia de Nicolaus de Lira, Latin MS 30, fol. 123v, Itália, c. 1402.

(C) Manchester, John Rylands University Library [Em linha]. Consultado a 7 julho 2020. Disponível em HTTPS://WWW.DIgITALCOLLECTIONS.MANCHESTER.AC.UK/VIEW/MS-LATIN-00030/252

$\mathrm{Na}$ arte medieval, diferentes seres angelicais têm em suas asas a presença de ocelos do pavão. O Arcanjo Miguel, líder do exército divino, aparece com asas de pavão no Livro de Horas de Margarida de Órleans (Fig. 12, século XV) e no tríptico do Último Julgamento, de Hans Memling (1440-1494), onde o arcanjo segura uma balança na mão direita e um báculo na esquerda, rodeado de mortos levantando de seus túmulos e demônios brigando por suas almas. O pintor flamengo também usa o pavão como personagem na peça Cenas da Paixão de Cristo (século XV), e confere penas de pavão desta vez nas asas do mensageiro Arcanjo Gabriel em duas obras representando a Anunciação (1450; 1465-1470). Parece que nas cenas da Anunciação é mesmo recorrente a representação de Gabriel com asas de pavão. Fra Angelico (1395-1455) e Fra Filippo Lippi (1406-1469) assim apresentam o anjo nas suas versões do episódio. 


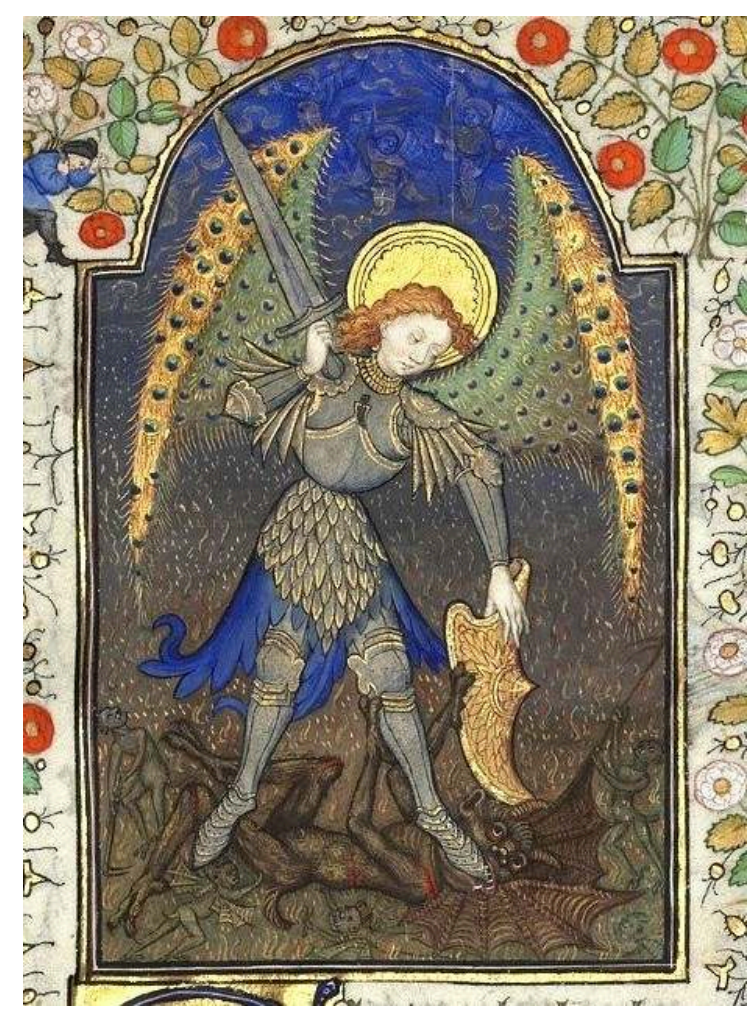

Fig. 12 - Livro de Horas de Margarida de Órleans, Dep. des manuscrits, Latin 1756B, f. 165r, França, 1401-1500.

(C) BnF - Bibliothèque nationale de France [Em linha]. (Consultado a 7 julho 2019). Disponível em HTTPS://gALLICA.BNF.FR/ARK:/12148/BTV1B52502614H/F341.IMAgE.

Misteriosa é a relação do pavão com São Tomé. Parece comum em diferentes códices que o apóstolo foi até a Índia, local por excelência dos pavões, sendo assim o animal um possível personagem nas histórias do apóstolo. Composta pelo dominicano Jacopo de Varazze (1228-1298), a coletânea hagiográfica Legenda Áurea anota: “Tomé estava na Cesaréia quando o Senhor lhe apareceu e disse: "O rei da Índia, Gondoforo, enviou seu ministro Abanes em busca de um arquiteto hábil. (...) Quando você tiver convertido os indianos, virá a mim com a palma do martírio"67. Outros textos também compõem o cenário do martírio do incrédulo com um grande número de pavões, até que foi morto quando confundido por um pavão pelo caçador, como descrito pelo viajante veneziano Marco Polo (1254-1324):

"Eles dizem que o Santo estava na floresta fora de seu eremitério rezando, e ao seu redor havia muitos pavões, (...) E um dos Idólatras (...), não vendo o Santo, atirou uma flecha em um dos pavões; e esta flecha atingiu o homem Santo no lado direito, de tal maneira que ele morreu com o ferimento, docilmente se dirigindo ao seu Criador" 68 .

Essa tradição, no entanto, não foi transmitida para as artes visuais da Idade Média.

$\mathrm{Na}$ Inglaterra, a ave aparece como atribuição ao arcebispo da Cantuária São Tomás Beckett (1118-1170), no século XIII. O santo é mostrado montado num pavão numa estátua usada como lembrança dada aos peregrinos da Cantuária (Fig. 13). Uma vez que na história do santo não é encontrada qualquer relação à ave, tal associação torna-se de difícil investigação. Seria uma figura triunfal do santo montado no orgulho do rei Henrique II de Inglaterra? Ou seria uma demonstração da promessa feita pelos peregrinos, que imitavam os cavaleiros em seus juramentos dos "votos do pavão"? 


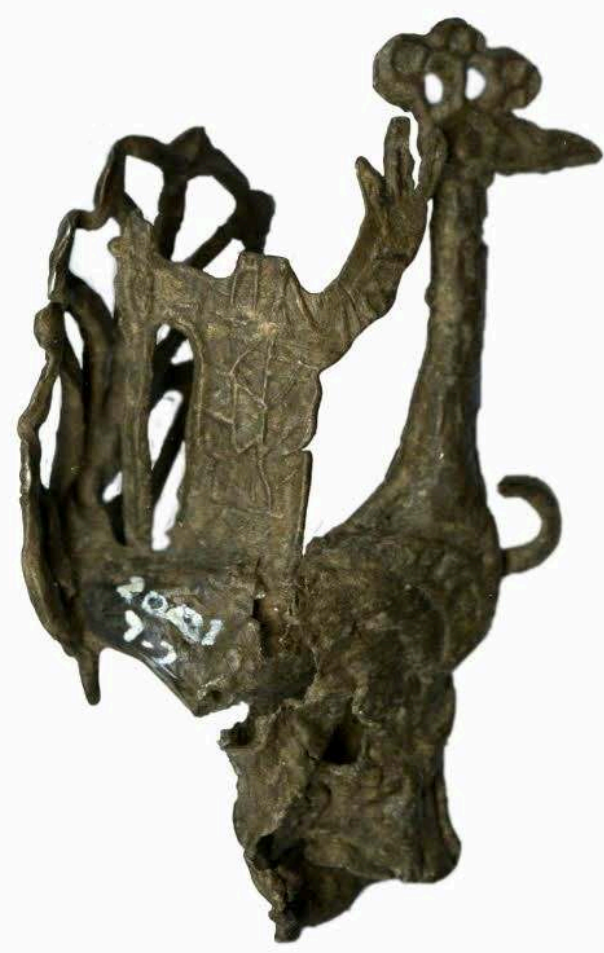

Fig. 13 - São Tomás Beckett montado num pavão, liga de chumbo, Canterbury, 1250-1350.

(C) MUSEU BRITÂNICO, THE TRUSTEES OF THE BRITISH MUSEUM [EM LINHA]. (CONSULTADO A 7 JULHO 2020). DISPONÍVEL EM HTTPS://RESEARCH.BRITISHMUSEUM.ORg/RESEARCH/COLLECTION_ONLINE/ COLLECTION_OBJECT_DETAILS/COLLECTION_IMAgE_GALLERY.ASPX? ASSETID=180731001\&OBJECTID=762026\&PARTID=1\#MORE-VIEWS.

A virgem mártir Santa Bárbara, além dos costumeiros elementos iconográficos da torre ou do cálice, também pode figurar segurando uma pena de pavão, como comprova a obra do Mestre do Sangue Sagrado, Madonna com as santas Catarinas e Bárbara (1509-1529, Fig. 14). Aqui, uma possível explicação vem da origem da Santa, que nasceu em Heliópolis, hoje Balbeque, no Líbano. Na Antiguidade, a cidade, então pertencente ao império de Alexandre, tinha o pavão como emblema ${ }^{69}$.

Além dos temas hagiográficos, o pavão ou suas penas aparecem na arte em quase todas as fases da vida de Cristo, desde as já descritas Anunciações. E, quando o anjo mensageiro não é imaginado com asas de pavão, o pássaro colorido aparece como espectador, como apresenta Fra Carnevale (1420-1484). Ele também é espectador da Natividade em duas peças de Fra Angelico (1395-1455). Girolamo dai Libri (1474-1555), em Madona e criança com santos (1520) mostra o pavão como o único representante do mundo animal na cena, evidenciado no alto de uma árvore. A ave é imaginada como habitante do Jardim do Éden, como na obra de Jacopo Bassano (1510-1592). Por fim, até nos últimos episódios da vida de Cristo o pavão está presente, como na Santa Ceia de Domenico Ghirlandaio (1449-1494).

71 As obras de arte mencionadas servem como comprovante de que o pavão figurou nas artes visuais, durante a longa Idade Média, não como um símbolo da vaidade e orgulho, e sim como um animal crístico, figurando em todos as cenas de Sua vida. E, além de Cristo, o pavão associa-se na arte com diversos santos. 


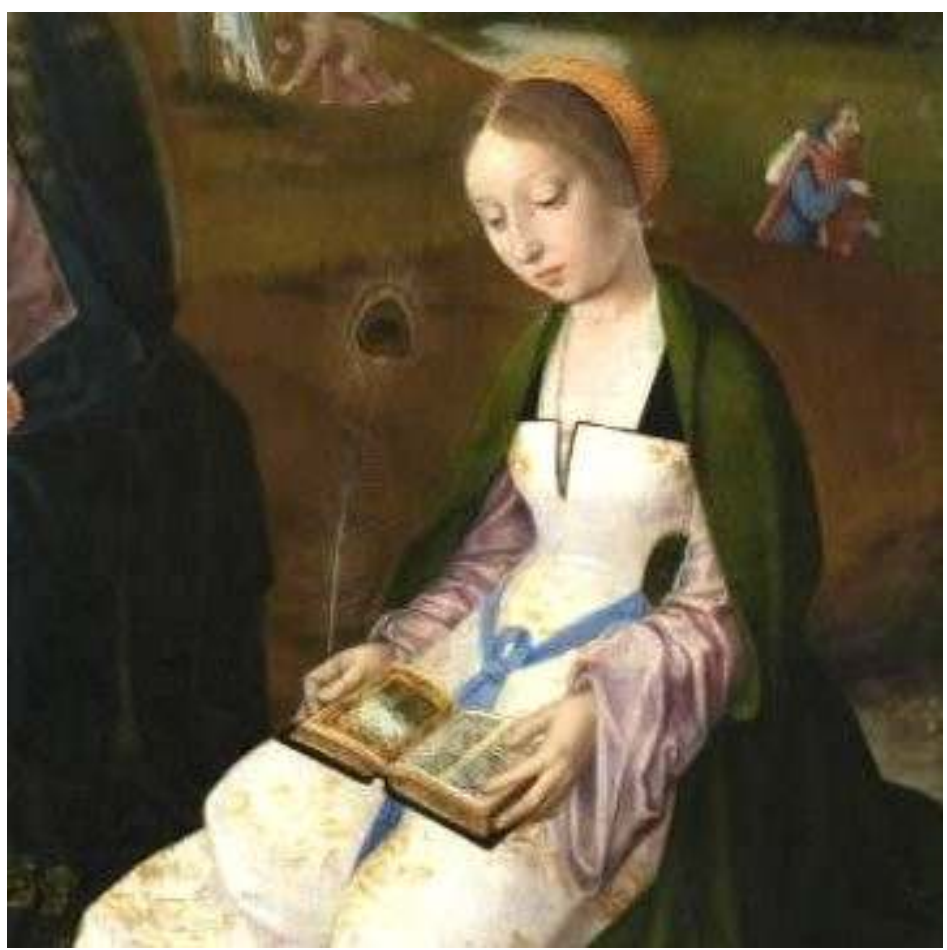

Fig. 14 - Master of the Holy Blood, Madonna com as santas Catarina e Bárbara, Flandres, 1509-1529, óleo sobre madeira, $122 \times 88.5 \times 6 \mathrm{~cm}$.

(C) Groeninge Museum Bruges [Em linha]. (Consultado a 7 julho 2019). Disponível em HTTP:/l VLAAMSEPRIMITIEVEN.VLAAMSEKUNSTCOLLECTIE.BE/EN/COLLECTION/MADONNA-WITH-THE-SAINTSCATHERINE-AND-BARBARA.

bonitos da natureza. Tal beleza inspirou a realeza e tornou o pavão um dos animais de prestígio nas artes decorativas, e também nas figurações simbólicas. Não é ao acaso que diversos monarcas elegeram o pavão como inspiração de seus tronos em diferentes tempos históricos. Além dos já referidos persas, o imperador Shah Jahan (1592-1666) também responsável pela construção do Taj Mahal - tinha em sua posse o Trono do Pavão. No Palácio de Linderhof, na Baviera, encontra-se também um trono decorado com pavões, comissionado pelo rei Luís II (1845-1886).

Por ser bonito e por ser exótico, o animal configurou-se como mercadoria de luxo, a partir de rotas indianas, fenícias, persas e helenísticas. Necessária devido à não participação do pavão em ondas migratórias, a partir das rotas comerciais que a ave colorida foi distribuída pela Europa.

Os simbolismos do pavão variaram de acordo com a tradição. Quando relacionado às culturas hindu e budista, o pavão remete a diferentes divindades. Nos mitos clássicos, é associado à Hera e Juno, a última sendo a deusa responsável pelo surgimento dos cem olhos do pavão. E, ainda na literatura clássica, a ave é encarada como símbolo da vaidade e do orgulho.

76 Na Idade Média, parece que o pavão foi um símbolo mais positivo que negativo. Foi essencialmente um símbolo da imortalidade de Cristo, herança pagã da associação entre a ave com a vida eterna, com o paraíso e outros temas fúnebres, o que representou tema preferido na pintura de frescos nas catacumbas romanas. Assim, nas artes visuais 
o pavão figurou como elemento decorativo, como símbolo da imortalidade, e como personagem acompanhante de vários santos e de cenas bíblicas.

Em relação aos bestiários, estes focam na beleza do animal, mas não como forma de transformá-lo apenas em símbolo de vaidade e orgulho. Os compositores usaram de tais atribuições como mensagem moralizante, a fim de inspirar humildade e caridade. Afinal, quando orgulhosa, a ave abre o seu leque multicolorido. Porém, ao mesmo tempo, expõe sua parte traseira. Ou como o Physiologus sugere, é desse orgulho e a vaidade do pavão que deriva sua tristeza ao ver os próprios pés. Conta-se pelo provérbio inglês: "O pavão tem respeitáveis penas, mas desleais pés".

\section{BIBLIOGRAFIA}

Fontes manuscritas

Aberdeen, University, Bestiário de Aberdeen, Ms. 24. Disponível em https://www.abdn.ac.uk/ bestiary/.

Library, Medicaen-Laurentian Library, Syriac Orthodox Resources - Miniatures from the Rabbula Gospels. Ms. Plut. I, 56. Disponível em http://sor.cua.edu/Bible/RabbulaMs.html.

Fontes impressas

ARISTÓTELES - History of Animals [Em linha]. Ed. Richard Cresswell, Project Gutenberg. (Consultado a 7 julho 2019). Disponível em http://www.gutenberg.org/files/59058/59058-h/ 59058-h.htm.

BARBER, Richard (Ed.) - Bestiary. Being an English Version of the Bodleian Library, Oxford, MS Bodley 764. Woodbridge: Boydell, 1999.

Bíblia de Jerusalém. São Paulo: Ed. Paulus, 2002.

CLARK, Willene B. (ed.) - The Medieval Book of Birds: Hugh of Fouilloy's Aviarium. (Medieval \& Renaissance Texts and Studies, 80). Binghamton, New York: State University of New York, 1992.

ELIANO, Cláudio - On The Nature Of Animals [Em linha]. Ed. A. F. Scholfield, 1958. (Consultado a 7 julho 2019). Disponível em http://www.attalus.org/translate/animals5.html.

ESOPO - Fábulas. Ed. Antônio Carlos Vianna. Porto Alegre: L\&PM Editores, 1997.

ISIDORO DE SEVILHA - Etimologias. Ed. Stephen A. Barney; W. J. Lewis; J. A. Beach; Oliver Berghof The Etymologies of Isidore of Seville. Cambridge: Cambridge University Press, 2006.

JACOPO DE VAZARRE - Legenda Áurea. Ed. Hilário Franco Júnior. São Paulo: Companhia das Letras, 2011.

MARCO POLO - The Travels of Marco Polo [Em linha], vol. 2. Ed. Henry Yule; Henri Cordier, Cap. XVIII. (Consultado a 7 julho 2019). Disponível em http://www.gutenberg.org/cache/epub/12410/ pg12410-images.html. 
PLINY THE ELDER - The Natural History [Em linha]. Ed. John Bostock, 1885. (Consultado a 7 julho 2019). Disponível em: http://www.perseus.tufts.edu/hopper/text?

doc=Perseus\%3Atext\%3A1999.02.0137\%3Abook\%3D8\%3Achapter\%3D50.

SANTO AGOSTINHO - A Cidade de Deus. Parte II. São Paulo: Vozes de Bolso, 2014.

SANTO ANTÓNIO - Sermão do Primeiro Domingo da Quaresma. Ed. Henrique Pinto Rema - Santo António: Obras Completas. Porto: Lello \& Irmão, 1987.

RAZI, Sharif (Trad.)- Nahjul Balagha: Peak of Eloquence. [Em linha]. DuasPublishing Project (Consultado a 7 julho 2019). Disponível em https://www.al-islam.org/nahjul-balagha-part-1sermons/sermon-165-allah-has-provided-wonderful-creations\#about-peacock.

Estudos

ALLISON, Christine - "YAZIDIS i. GENERAL". in Encyclopædia Iranica [Em linha]. (Consultado a 7 julho 2019). Disponível em http://www.iranicaonline.org/articles/yazidis-i-general-1.

ANĐELKOVIĆ, Jelena; ROGIĆ, Dragana; NIKOLIĆ, Emilija - "Peacock as a sign in the late antique and early christian art”. Archeology and Science 6 (2010), pp. 231- 268.

BEER, Robert - The Handbook of Tibetan Buddhist Symbols. London, Chicago: Serindia, 2003.

BERNARD, Meehan - The Book of Kells: An Illustrated Introduction to the Manuscript in Trinity College Dublin. New York: Thames and Hudson, 1994.

CAVALLINI, Andrea - La penna del pavone: Bibbia ed esegesi in Gioivanni Scoito Eriugena. Roma: Città Nuova, 2016.

CHEVALIER, Jean; GHEERBRANDT, Alain - Dictionary of Symbols. Paris: Penguin Reference, 1982.

CHEVALLIER, Jim (Ed.) - How To Cook A Peacock: Le Viandier: Medieval Recipes From The French Court. California: Chez Jim, 2008.

CHOSKYI, Jampa - "Symbolism of Animals in Buddhism". Revista Buddhist Himalaya [Em linha] 1/1 (1988). (Consultado a 7 julho 2019). Disponível em: http://ccbs.ntu.edu.tw/FULLTEXT/JR-BH/ bh117490.htm.

COOPER, Jean C. - An Illustrated Encyclopaedia of Tradicional Symbols. London: Thames \& Hudson, 1978.

COTTERELL, Arthur - A Dictionary of World Mythology. New York: Perigee Book, 1979.

DALAL, Roshen - Hinduism: An alphabetic guide. New Dhéli: Penguin, 2011.

DE JONG, Albert - "The Peacock and the Evil One". in ALLISON, Christine; JOISTEN-PRUSCHKE, Anke; WENDTLAND, Antje - From Daena to Din: Religion, Kultur und Sprache in der iranischen Welt. Wiesbaden: Harrassowitz Verlag, 2009, pp. 303-320.

DE LONGUYON, Jacques - Una redazione latina inedita dei voti del Pavone. A cura do Vincenzo Licitra. Spoleto: Centro italiani di studi sull'alto Medioevo, 1961.

DIXON-KENNEDY, Mike - Encyclopedia of Grego-Roman Mythology. Santa Bárbara: ABC-CLIO, 1998.

EDMONDS, John Maxwell (Ed.) - The Fragments of Attic Comedy. Vol. II. Leiden: E. J. Brill, 1959.

FRIEDMAN, John B. - "Peacocks and Preachers: Analytic Technique in Marcus of Orvieto's Liber de moralitatibus, Vatican lot. MS S93S”. in CLARK, Willene B.; McMUNN, Meradith T. - Beasts and birds of the Middle Ages. Philadelphia: University of Pennsylvania Press, 1989, pp. 179-196.

FURLANI, Giuseppe - Gli adoratori del pavone: I Yezidi: i testi sacri di una religione perseguitata. Milano: Joovence, 2016. 
JACKSON, Christine E. - Peacock. London: Reaktion Books, 2016.

KANG, Kyu-suk - “The Peacock”. Journal of Symbols \& Sandplay Therapy 4/1 (2013), pp. 35-43.

LEO, Dominic - Images, Texts, and Marginalia in a "Vows of the Peacock" Manuscript. New York: Brill, 2013.

LOTHER, Helmut - Der Pfau in der altchristlichen Kunst. Leipzig: Dieterich, 1929.

LUDVIK, Catherine - Sarasvati, Riverine Goddess of Knowledge: From the manuscript-carrying Vinaplayer to the Weapon-wielding Defender of the Dharma. Leiden, Boston: Brill's Indological Library, 2007.

REIMBOLD, Ersnt Thomas - Der Pfau: Mythologie und Symbolik. Muenchen: Callwey, 1983.

RODRIGUES, Alessandro Pereira - Apício, De Re Coquinaria I-III: Introdução, tradução e notas. Rio Grande do Sul: Universidade Federal, 2010. Trabalho de Conclusão de Curso. (Consultado a 7 julho 2019). Disponível em https://lume.ufrgs.br/handle/10183/29146.

SYME, Alison - "Taboos and the Holy in Bodley 764". in HASSIG, Debra (ed.) - The Mark of the Beast: Bestiary in Life, Art and Literature. New York, London: Routledge, 200, pp. 163-184.

TESTINI, Pasquale - "Il simbolismo degli animali nell'arte figurativa paleocristiana". in L'uomo di fronte al mondo animale nell'Alto Medioevo. Atti (dal 7 al 13 aprile 1983). Vol. 2. Spoleto: Centro Italiani di Studi Sull'Alto Medioevo, 1987, pp. 1107-1179.

THANKAPPAN, P. Nair - “The Peacock Cult in Asia”. Asian Folklore Studies 33/2 (1974), pp. 93-170.

TRIFUNOVIC, Dorde - Fiziolog: slovo o hodecim i letecim stvorenjima. Pozarevac: Branicevo, 1973.

VARGAS, Ivette - “Snake-Kings, Boars' Heads, Deer Parks, Monkey Talk: Animals as Transmitters and Transformers in Indian and Tibetan Buddhist Narratives". in WALDAU, Paul; PATTON, Kimberly (Eds.) - A Communion of Subjects: Animals in Religion, Science, \& Ethics. New York: Columbia University Press, 2006, pp. 218-238.

WERNESS, Hope B - Continuum Encyclopedia of Animal Symbolism in World Art. New York, London: Continuum, 2006.

WITZEL, Michael - "Substrate Languages in Old Indo-Aryan". Electronic Journal of Vedic Studies [Em linha] 5/1 (1999), pp. 1-67. (Consultado a 7 julho 2019). Disponível in https://doi.org/10.11588/ ejvs.1999.1.828.

\section{NOTAS}

1. CHEVALIER, Jean; GHEERBRANDT, Alain - Dictionary of Symbols. Paris: Penguin Reference, 1982, p. 741.

2. ESOPO - Fábulas. Ed. Antônio Carlos Vianna. Porto Alegre: L\&PM Editores, 1997, p. 48; ELIANO, Cláudio - On The Nature of Animals [Em linha]. Livro 5, 21. Ed. A. F. Scholfield, 1958. [Consultado a 7 julho 2019]. Disponível em http://www.attalus.org/translate/ animals5.html.

3. COOPER, Jean C. - An Illustrated Encyclopaedia of Tradicional Symbols. London: Thames \& Hudson, 1978, p. 127.

4. THANKAPPAN, P. Nair - “The Peacock Cult in Asia”. Asian Folklore Studies 33/2 (1974), pp. 93-170, p. 131.

5. CHEVALIER, Jean; GHEERBRANDT, Alain - Dictionary of Symbols ..., p. 741. 
6. CHEVALIER, Jean; GHEERBRANDT, Alain - Dictionary of Symbols ..., p. 741.

7. COTTERELL, Arthur - A Dictionary of World Mythology. New York: Perigee Book, 1979, p. 74.

8. BEER, Robert - The Handbook of Tibetan Biddhist Symbols. Londres, Chicago: Serindia, 2003, p. 122.

9. LUDVIK, Catherine - Sarasvati, Riverine Goddess of Knowledge: From the manuscript-carrying Vinaplayer to the Weapon-wielding Defender of the Dharma. Leiden, Boston: 2007, p. 1.

10. COTTERELL, Arthur - A Dictionary of World Mythology ..., 1979, p. 85.

11. COOPER, J. C - An Illustrated Encyclopaedia of Tradicional Symbols ..., p. 127.

12. THANKAPPAN, P. Nair - “The Peacock Cult in Asia” ..., pp. 93-170, p. 113.

13. PLINY THE ELDER - The Natural History [Em linha]. Book VIII, chapter 50 (32). Ed. John Bostock, 1885. [Consultado a 7 julho 2019]. Disponível em http:// www.perseus.tufts.edu/hopper/text?

doc=Perseus\%3Atext\%3A1999.02.0137\%3Abook\%3D8\%3Achapter\%3D50.

14. CHOSKYI, Jampa - "Symbolism of Animals in Buddhism". Revista Buddhist Himalaya [Em linha], Vol. 1, n. 1 (1988). [Consultado a 7 julho 2019]. Disponível em http://ccbs.ntu.edu.tw/FULLTEXT/ JR-BH/bh117490.htm.

15. KANG, Kyu-suk - “The Peacock”. Journal of Symbols \& Sandplay Therapy 4/1 (2013), pp. 35-43.

16. JACKSON, Christine E. - Peacock. Londres: Reaktion Books, 2016, p. 86.

17. Bíblia de Jerusalém. São Paulo: Ed. Paulus, 2002. 1Rs, 10:21,22, e repetido em 2Cr, 9:21.

18. THANKAPPAN, P. Nair - “The Peacock Cult in Asia” ..., pp. 93-170, p. 128.

19. P. THANKAPPAN, Nair - “The Peacock Cult in Asia” ..., pp. 93-170, p. 128.

20. JACKSON, Christine E-Peacock ..., p. 89.

21. COTTERELL, Arthur - A Dictionary of World Mythology ..., p. 143.

22. EDMONDS, John Maxwell - The Fragments of Attic Comedy. Vol. II. Leiden: E. J. Brill, 1959, p. 249.

23. COTTERELL, Arthur - A Dictionary of World Mythology ..., p. 146.

24. WERNESS, Hope B - Continuum Encyclopedia of Animal Symbolism in World Art. New York, London: Continuum, 2006, p. 320.

25. COTTERELL, Arthur - A Dictionary of World Mythology ..., p. 143.

26. DIXON-KENNEDY, Mike - Encyclopedia of Grego-Roman Mythology. Santa Bárbara: ABC-CLIO, 1998 , p. 45.

27. THANKAPPAN, P. Nair - "The Peacock Cult in Asia” ..., pp. 93-170, p. 10.

28. ESOPO - Fábulas ..., p. 48.

29. ARISTÓTELES - History of Animals [Em linha]. Ed. Richard Cresswell, Livro I, cap. I: 16 (p. 6); Livro VI, cap. IX: 1 (p. 148). [Consultado a 7 Julho 2019]. Disponível em http:// www.gutenberg.org/files/59058/59058-h/59058-h.htm.

30. JACKSON, Christine E - Peacock ..., p. 96.

31. JACKSON, Christine E - Peacock ..., p. 94.

32. PLINY THE ELDER - The Natural History [Em linha]. Book X, chapter 22 (20), 13. Ed. John Bostock, 1885. [Consultado a 7 Julho 2019]. Disponível em http://www.perseus.tufts.edu/hopper/ text?doc=Perseus\%3Atext\%3A1999.02.0137\%3Abook\%3D10\%3Achapter\%3D22. Tradução do autor.

33. ELIANO, Cláudio - On The Nature Of Animals..., Livro 5, cap. 21. Disponível em: http:// www.attalus.org/translate/animals5.html. Tradução do autor.

34. JACKSON, Christine E - Peacock ..., p. 55.

35. SANTO AGostinHO - A Cidade de Deus. Parte II, cap. IV, 1. São Paulo: Vozes de Bolso, 2014, p. 575. 
36. FRIEDMAN, John B. - "Peacocks and Preachers: Analytic Technique in Marcus of Orvieto's Liber de moralitatibus, Vatican lot. MS S93S”. in CLARK, Willene B.; McMUNN, Meradith T. - Beasts and birds of the Middle Ages. Philadelphia: University of Pennsylvania Press, 1989, p. 189.

37. FRIEDMAN, John B. - "Peacocks and Preachers: Analytic Technique in Marcus of Orvieto's Liber de moralitatibus, Vatican lot. MS S93S” ..., p. 189.

38. JACKSON, Christine E. - Peacock ..., p. 48.

39. RODRIGUES, Alessandro Pereira - Apício, De Re Coquinaria I-III: Introdução, tradução e notas. Rio Grande do Sul: Universidade Federal, 2010, p.50. (Consultado a 7 julho 2019). Trabalho de Conclusão de Curso. Disponível em https://lume.ufrgs.br/handle/10183/29146.

40. CHEVALLIER, Jim - How To Cook A Peacock: Le Viandier: Medieval Recipes From The French Court. California: Chez Jim, 2008, p. 13.

41. A prática foi popularizada por uma obra, Tournoi de Chauvency, mais especificamente na narrativa poética Voeux du Pavon (Os votos do pavão), de Jacques du Longuyon (séc. XIV), que integra o círculo de histórias de Alexandre, o Grande. (LEO, Dominic - Images, Texts, and Marginalia in a "Vows of the Peacock" Manuscript. New York: Brill, 2013).

42. CHEVALIER, Jean; GHEERBRANDT, Alain - Dictionary of Symbols ..., p. 741. Tradução do autor.

43. ANDELKOVIC, Jelena; ROGIC, Dragana; NIKOLIC, Emilija - "Peacock as a sign in the late antique and early christian art”. Archeology and Science 6 (2010), pp. 231-248, p. 241.

44. Bíblia de Jerusalém ..., Ap,2:7.

45. DALAL, Roshen - Hinduism: An alphabetic guide. New Dhéli: Penguin, 2011, p. 145.

46. WITZEL, Michael - "Substrate Languages in Old Indo-Aryan". Electronic Journal of Vedic Studies [Em linha] 5/1 (1999), pp. 1-67. (Consultado a 7 julho 2019). Disponível in https://doi.org/10.11588/ejvs.1999.1.828.

47. Bíblia de Jerusalém ..., Ap, 12:9.

48. DE JONG, Albert - "The Peacock and the Evil One". in ALISSON, Christine; JOISTEN-PRUSCHKE, Anke; WENDTLAND, Antje - From Daena to Din: Religion, Kultur und Sprache in der iranischen Welt. Wiesbaden: Harrassowitz Verlag, 2009, pp. 304-307.

49. RAZI, Sharif (Trad.)- Nahjul Balagha: Peak of Eloquence. [Em linha]. DuasPublishing Project (Consultado a 7 julho 2019). Disponível em https://www.al-islam.org/nahjulbalagha-part-1-sermons/sermon-165-allah-has-provided-wonderful-creations\#aboutpeacock.

50. DE JONG, Albert - “The Peacock and the Evil One”..., pp. 304-307.

51. COOPER, J. C - An Illustrated Encyclopaedia of Tradicional Symbols ..., p. 127.

52. Bestiário de Aberdeen, f. 61r. (Consultado a 3 julho 2019). Disponível em https:// www.abdn.ac.uk/bestiary/ms24/f61r. Tradução do autor.

53. SYME, Alison - "Taboos and the Holy in Bodley 764". in HASSIG, Debra (ed.) - The Mark of the Beast: Bestiary in Life, Art and Literature. New York, London: Routledge, 200, p. 168.

54. Bíblia de Jerusalém ..., Jo, 9:39-41.

55. Bestiário de Aberdeen, f. 59v. (Consultado a 3 julho 2019). Disponível em https:// www.abdn.ac.uk/bestiary/ms24/f59v. Tradução do autor.

56. Bestiário de Aberdeen, f. 59v. (Consultado a 3 julho 2019). Disponível em https:// www.abdn.ac.uk/bestiary/ms24/f59v. Tradução do autor. 
57. CLARK, Willene B. (ed.) - The Medieval Book of Birds: Hugh of Fouilloy's Aviarium. (Medieval \& Renaissance Texts and Studies, 80). Binghamton, New York: State University of New York, 1992, pp. 245-251.

58. Bestiário de Aberdeen, f. 60v-61r. (Consultado a 7 julho 2019). Disponível em: https:// www.abdn.ac.uk/bestiary/ms24/f60v. Tradução do autor.

59. Bíblia de Jerusalém ..., Mat, 5:29.

60. Bestiário de Aberdeen [Em linha], f. 61r. (Consultado a 7 julho 2020). Disponível em https:// www.abdn.ac.uk/bestiary/ms24/f61r. Tradução do autor.

61. SANTO ANTÓNIO - Sermão do Primeiro Domingo da Quaresma. Ed. Henrique Pinto Rema - Santo António: Obras Completas. Porto: Lello \& Irmão, 1987, p. 96.

62. ANĐELKOVIĆ, Jelena; ROGIĆ, Dragana; NIKOLIĆ, Emilija - "Peacock as a sign in the late antique and early christian art”. Archeology and Science 6 (2010), pp. 231-268, p. 245. Tradução do autor.

63. Bíblia de Jerusalém ..., Jo 6:38.

64. BERNARD, Meehan - The Book of Kells: An Illustrated Introduction to the Manuscript in Trinity College Dublin. New York: Thames and Hudson, 1994.

65. Paris, Bibliothèque nationale de France, Apocalipse de Paris, Ms. Neérlandais 3, f. 5 r. Século XV. (Consultado a 3 julho 2019). Disponível em https://archivesetmanuscrits.bnf.fr/ark:/12148/ cc1020156.

66. ALLISON, Christine - "YAZIDIS i. GENERAL". Encyclopædia Iranica [Em linha]. (Consultado a 3 julho 2019). Disponível em: http://www.iranicaonline.org/articles/yazidis-i-general-1

67. JACKSON, Christine E. - Peacock ..., pp. 81-82.

68. MARCO POLO - The Travels of Marco Polo [Em linha], vol. 2. Ed. Henry Yule; Henri Cordier, Cap. XVIII. (Consultado a 7 julho 2020). Disponível em http:// www.gutenberg.org/cache/epub/12410/pg12410-images.html. Tradução do autor.

69. JACKSON, Christine E. - Peacock ..., p. 90.

\section{RESUMOS}

O pavão é considerado um dos mais bonitos animais da natureza. Essa beleza, no que diz respeito ao imaginário, torna-se elemento-chave nas narrativas e nas artes que associam o pavão com as divindades hindus e budistas, com o orgulho e com a vaidade. Este artigo busca apresentar de que forma os simbolismos do pavão foram transmitidos e adaptados, desde a Índia Antiga até a Europa Medieval, onde a ave figurou na criatividade cristã como emblema da imortalidade de Cristo e dos pregadores da Igreja, acompanhando também narrativas hagiográficas e imagens bíblicas.

The peacock is considered one of the most beautiful animals in nature. This beauty, concerning the imaginary, becomes a key element in the narratives and arts that associate the peacock with the Hindu and Buddhist deities, but also with the pride and the vanity. This article tries to show how the symbolism of the peacock was transmitted and adapted from Ancient India to Medieval Europe, where the bird figured in the Christian creativity as an emblem of the immortality of Christ and the preachers of the Church, along with hagiographical narratives and biblical images. 
ÍNDICE

Keywords: Bestiary, Symbolism, Peacock, Middle Ages, Imaginary

Palavras-chave: Bestiário, Simbolismo, Pavão, Idade Média, Imaginário

\section{AUTOR}

\section{MARCELO AMATO CARDOSO}

Investigador Independente. Lisboa, Portugal. marcelocardosoamato@hotmail.com. https:// orcid.org/0000-0001-6986-4331 